Kennesaw State University

DigitalCommons@Kennesaw State University

Faculty Publications

7-29-2021

\title{
Addressing Student Engagement During COVID-19: Secondary STEM Teachers Attend to the Affective Dimension of Learner Needs
}

\author{
Tiffany Roman \\ troman5@kennesaw.edu \\ Laurie Brantley-Dias \\ Kennesaw State University, Idias@kennesaw.edu \\ Michael Dias \\ Kennesaw State University, mdias@kennesaw.edu \\ Belinda Edwards \\ Kennesaw State University, bedwards@kennesaw.edu
}

Follow this and additional works at: https://digitalcommons.kennesaw.edu/facpubs

Part of the Educational Technology Commons, Science and Mathematics Education Commons, and the Secondary Education and Teaching Commons

\section{Recommended Citation}

Roman, Tiffany; Brantley-Dias, Laurie; Dias, Michael; and Edwards, Belinda, "Addressing Student Engagement During COVID-19: Secondary STEM Teachers Attend to the Affective Dimension of Learner Needs" (2021). Faculty Publications. 4817.

https://digitalcommons.kennesaw.edu/facpubs/4817

This Article is brought to you for free and open access by DigitalCommons@Kennesaw State University. It has been accepted for inclusion in Faculty Publications by an authorized administrator of DigitalCommons@Kennesaw State University. For more information, please contact digitalcommons@kennesaw.edu. 


\section{Addressing student engagement during COVID-19: Secondary STEM teachers attend to the affective dimension of learner needs}

\section{Tiffany A. Roman, Laurie Brantley-Dias, Michael Dias \& Belinda Edwards}

To cite this article: Tiffany A. Roman, Laurie Brantley-Dias, Michael Dias \& Belinda Edwards (2021): Addressing student engagement during COVID-19: Secondary STEM teachers attend to the affective dimension of learner needs, Journal of Research on Technology in Education, DOI: 10.1080/15391523.2021.1920519

To link to this article: https://doi.org/10.1080/15391523.2021.1920519

Published online: 29 Jul 2021.

Submit your article to this journal $\square$

Wll Article views: 114

à

View related articles $\sqsubset$

View Crossmark data $₫$ 


\title{
Addressing student engagement during COVID-19: Secondary STEM teachers attend to the affective dimension of learner needs
}

\author{
Tiffany A. Roman (D), Laurie Brantley-Dias (D), Michael Dias (D) and Belinda Edwards (D) \\ Kennesaw State University, Kennesaw, Georgia, USA
}

\begin{abstract}
This case study examines how a cohort of eleven induction secondary STEM teachers engaged learners during the onset of COVID-19 and their designs for student engagement given an online or blended teaching context in fall 2020. Participants attended a summer professional development workshop guided by trauma-informed teaching practices and learner engagement conceptual frameworks. Through the analysis of teacher artifacts and interviews, we identified dimensions of student engagement that teachers prioritized. Results indicate a marked increase in teachers' attention to affective and social dimensions of learner engagement. We argue that teacher awareness and action in the affective domain of student engagement is critical during times of trauma.
\end{abstract}

\author{
ARTICLE HISTORY \\ Received 18 September \\ 2020 \\ Revised 24 March 2021 \\ Accepted 19 April 2021

\section{KEYWORDS} \\ Instructional technology; \\ math education; \\ science education; \\ student engagement; \\ learner engagement; \\ COVID-19; \\ STEM; \\ induction teachers; \\ professional \\ development; \\ remote teaching; \\ online learning; \\ distance education; \\ pandemic
}

\section{Introduction}

With the emergence of the COVID-19, K-12 teachers in the U.S. had to quickly shift from face-to-face instruction to rapid online learning. Hodges et al. (2020) defined this period of instruction as emergency remote teaching, which involves a "temporary shift of instructional delivery to an alternate delivery mode due to crisis circumstances" (para. 13) with the intent of returning to the original teaching modality once the crisis has abated. Given the logistical challenges of distributing a SARS-CoV-2 vaccine (Lurie et al., 2020), the need to provide distance learning and/or socially distant classroom instruction continued into 2021 along with the potential for temporary school closures should the virus reemerge (Melnick et al., 2020). Thus, since spring 2020, rapid online learning has been an ongoing reality due to COVID-19.

Adding to the complexity of continued online and blended K-12 teaching due to COVID-19, teachers and students are operating within a time of crisis and trauma. Horesh and Brown (2020) argued that COVID-19 should be viewed from a perspective of trauma, which is particularly relevant for marginalized communities who have been disproportionately affected by COVID-19 (Kantamneni, 2020). In addition to COVID-19, in 2020, trauma emerged from the social and political unrest following the deaths of George Floyd, Ahmaud Arbery, Breonna Taylor, and Jacob Blake. Many students, parents, and teachers have likely experienced racial battle fatigue (RBF), which Smith et al. (2007) defined as the mounting result of re-occurring race-related stress responses (psychosocial, physiological, and behavioral) to distressing or life-threatening

CONTACT T. A. Roman troman5@kennesaw.edu Instructional Technology, Kennesaw State University, 585 Cobb Ave NW, MD 0127, Kennesaw, GA 30144-5588, USA 
mental and emotional conditions. Not unlike historical trauma related to acts of injustice, recurring microaggressions, and systemic racism, navigating the barriers of COVID-19 can result in trauma (Music, 2020). To engage learners during times of crisis, it is recommended that educators use trauma-informed teaching practices (Carello, 2020) which include being aware and responsive to forms of privilege and oppression; however, the ways in which teachers are addressing trauma with their students during COVID-19 remains unclear (Roman, 2020). Trauma-based research is urgently needed, and educators are one group that can help those traumatized by the COVID-19 crisis (Horesh \& Brown, 2020).

\section{Study rationale}

K-12 teaching during COVID-19 requires educators to engage students during a time of crisis and trauma in socially distant and/or online learning environments. Teachers in spring 2020 implemented innovative teaching methods to cope with the challenges that arose (see Johnson et al., 2020). It has been argued that the "needs that emerged during the transition to emergency remote teaching [in spring 2020] should inform strategies for student and faculty support" (Johnson et al., 2020, p. 18), yet it is unclear what teachers desired to change and how they wanted to adapt their instruction given that the return to school in fall 2020 varied (e.g., online, hybrid, fully face-to-face) depending on school context. Identifying the pedagogical supports that educators need for online instruction remains of critical importance as those insights can guide professional development (PD) offerings (Johnson et al., 2020).

To address the needs of teachers during rapid online learning, this study examined how a cohort of math and science secondary teachers engaged learners during emergency remote teaching and how they designed instruction for learner engagement in fall 2020. Guided by trauma-informed teaching practices (Carello, 2020) and learner engagement conceptual frameworks (Bond \& Bedenlier, 2019; Borup, Graham, et al., 2020), a cohort of eleven teacher participants from nine schools across five districts in a large metropolitan area in the southeast U.S. volunteered to participate in a summer PD experience that supported their personalized learning goals for fall 2020.

The purpose of this study was to investigate and support teachers' online and blended teaching practices by explicating dimensions of student engagement and trauma-informed teaching principles so that teachers could generate more responsive practice. Within online learning, behavioral indicators of engagement are the easiest to track (Henrie et al., 2015) and identify (e.g., student logins, homework submissions). This attention to metrics is only one dimension of engagement, however, and if teachers are not aware of and encouraged to attend to the affective and social sides of student engagement, the cognitive dimensions will be under-realized. We argue that intentional support for affective and social engagement is always critical, particularly during times of trauma.

\section{Review of literature}

Student engagement is an under-theorized construct (Bond et al., 2020; Henrie et al., 2015) and its definitions vary widely (Appleton et al., 2008; Fredricks et al., 2004; Halverson \& Graham, 2019). A commonality across prior research is that the construct is multidimensional (Finn \& Zimmer, 2012) although the number of student engagement dimensions can vary, ranging from two to four, and indicators of each dimensions are also known to differ. The three student engagement dimensions that are widely accepted include behavioral, affective/emotional, and cognitive (Fredricks et al., 2004; Fredricks, Filsecker, et al., 2016). Each dimension is distinct yet interrelated. Cognitive engagement is described as a "student's level of investment in learning" (Fredricks, Wang, et al., 2016, p. 6) which includes the willingness to exert effort to understand complex ideas, self-regulation, and deep learning strategies (Bond \& Bedenlier, 2019; Fredricks 
et al., 2004). Behavioral engagement is defined as positive conduct, participation, effort, non-disruptive behavior, attention, and persistence (Fredricks et al., 2004). Affective engagement, also known as emotional engagement, centers on reactions to peers, teachers, school, and/or academics, one's sense of belonging, as well as relating to a particular school or subject (Fredricks, Wang, et al., 2016, p. 6).

Within the past decade, an additional dimension of student engagement has emerged focused on social engagement. Research in this area includes how positive social forms of engagement shape affect (Linnenbrink-Garcia et al., 2011), and descriptions of prosocial behaviors of students within the classroom (Finn \& Zimmer, 2012). In the area of middle and high school math and science, Fredricks, Wang, et al. (2016) identified domain-specific aspects of social engagement and suggested that future research should explore if social engagement is a moderator of students' behavioral, emotional, and cognitive engagement. More recently, Xie (2021) argued that considerations of social engagement (e.g., peer/instructor interactions) are important for those who seek to create empathic designs for learners who have shifted to digital learning environments due to COVID-19.

To provide clarity on the construct of student engagement used within this study, we define student engagement as:

the energy and effort that students employ within their learning community, observable via any number of behavioral, cognitive, affective, or social indicators across a continuum. It is shaped by a range of structural and internal influences, including the complex interplay of relationships, learning activities, and the learning environment. (Bond et al., 2020, p. 3)

Our definition includes social engagement as a fourth dimension, which aligns to the aspects of social engagement proposed by Fredricks, Wang, et al. (2016), but differs from Bond et al's (2020) definition of student engagement as they limited their scope to behavioral, cognitive, and affective indicators.

In the following sections, we overview indicators of student engagement across the various dimensions (cognitive, behavioral, affective, and social). We define social engagement indicators for this study. Additionally, we delve into student engagement research in STEM domains as a means of situating the learning context of this research.

\section{Dimensions of student engagement}

Dimensions of student engagement are comprised of a range of indicators (Bond \& Bedenlier, 2019; Bond et al., 2020; Fredricks et al., 2004; see Table 1). The term 'indicator' is intended to represent "a manifestation of student engagement" that is "expressed-and eventually observable and measurable-through cognitive, affective or behavioral action or reaction" (Bond \& Bedenlier, 2019 , p. 3). Indicators exist on a continuum, which can suggest engagement (see Table 1) or disengagement (see Table 2).

Bond et al. (2020) compiled indicators for cognitive, behavioral, and affective dimensions of student engagement sourced from a range of literature (see Table 1); however, Bond et al. (2020) did not treat social engagement as a distinct indicator. Since Fredricks, Wang, et al. (2016) recommended that student engagement include the dimension of social engagement, we reviewed the indicators proposed by Bond et al. (2020) and identified the indicators that exemplified social engagement (e.g., learning from peers, asking teacher or peers for help, positive interactions with peers and teachers) across the various dimensions. By identifying social engagement indicators, we seek to advance the previous work by Bond et al. (2020) who identified indicators across three dimensions (cognitive, affective, behavioral) by adding the fourth indicator (social).

\section{Student engagement in STEM}

While behavioral and cognitive engagement are essential to STEM learning, research supports collaborative and dialogic instruction requiring affective and social dimensions of student 
Table 1. Indicators of student engagement.

\begin{tabular}{|c|c|c|c|}
\hline Cognitive engagement & Behavioral engagement & Affective engagement & Social engagement \\
\hline $\begin{array}{l}\text { Purposeful } \\
\text { Critical thinking } \\
\text { Self-Regulation } \\
\text { Integrating ideas } \\
\text { Setting learning goals } \\
\text { Operational Reasoning } \\
\text { Doing extra to learn more } \\
\text { Follow through/ care/ } \\
\text { thoughtfulness } \\
\text { Reflection } \\
\text { Positive self-perceptions \& } \\
\text { self-efficacy } \\
\text { Concentration/focus } \\
\text { Preference for challenging } \\
\text { task } \\
\text { Deep learning } \\
\text { Use of sophisticated } \\
\text { learning strategies } \\
\text { Justifying decisions } \\
\text { Positive perceptions of } \\
\text { teacher support }\end{array}$ & $\begin{array}{l}\text { Effort } \\
\text { Attendance } \\
\text { Positive conduct } \\
\text { Study habits } \\
\text { Attempting } \\
\text { Action/initiation } \\
\text { Developing agency } \\
\text { Homework completion } \\
\text { Confidence } \\
\text { Participation/involvement } \\
\text { Assuming responsibility } \\
\text { Developing multidisciplinary } \\
\text { skills } \\
\text { Attention/focus } \\
\text { Time on task/staying on } \\
\text { task/persistence } \\
\text { Accessing course material } \\
\text { Identifying opportunities \& } \\
\text { challenges }\end{array}$ & $\begin{array}{l}\text { Enthusiasm } \\
\text { Interest } \\
\text { Enjoyment } \\
\text { Sense of belonging } \\
\text { Sense of well-being } \\
\text { Pride } \\
\text { Satisfaction } \\
\text { Vitality/Zest } \\
\text { Excitement } \\
\text { Curiosity } \\
\text { Feeling appreciated } \\
\text { Confidence } \\
\text { Sense of connectedness to } \\
\text { school/university } \\
\text { Positive attitude about } \\
\text { learning/ values learning }\end{array}$ & $\begin{array}{l}\text { Trying to understand other's } \\
\text { ideas } \\
\text { Teaching self \& peers } \\
\text { Learning from peers } \\
\text { Asking teacher or peers for } \\
\text { help } \\
\text { Supporting \& encouraging } \\
\text { peers } \\
\text { Interactions (peers, teacher, } \\
\text { content, technology) } \\
\text { Positive interactions with } \\
\text { peers \& teachers }\end{array}$ \\
\hline
\end{tabular}

Table 2. Indicators of student disengagement.

\begin{tabular}{llll}
\hline Cognitive disengagement & Behavioral disengagement & Affective disengagement & Social disengagement \\
\hline Aimless & Procrastination & Boredom & Unwilling (to share ideas or \\
Helpless & Giving up & Frustration & work with others) \\
Resigned & Restlessness & Anger & Disinterest (in others' ideas) \\
Opposition/rejection & Half-hearted & Sadness & \\
Avoidance & Unfocused/inattentive & Worry/anxiety & \\
Apathy & Distracted & Shame & \\
Hopeless & Mentally withdrawn & Self-blame & \\
Pressured & Burned out/exhausted & Overwhelmed & \\
& Unprepared & Dislike & \\
& Absent & Disappointment & \\
& Poor conduct & & \\
\hline
\end{tabular}

Adapted from Bond et al., 2020 who sourced the indicators from a range of literature: Appleton et al. (2008), Filsecker and Kerres (2014), Fredricks, Wang, et al. (2016), Fredricks et al. (2004), Henrie et al. (2015), Kahu (2013), Mahatmya et al.

(2012), Redmond et al. (2018), Reeve (2012), Skinner and Pitzer (2012), and Zepke and Leach (2010).

engagement. A challenge within STEM teaching is that it is often focused on a narrow range of procedural skills, regardless of whether students work in groups, individually, or use technology (Mullis et al., 2004, 2012). Instruction that is predominantly teacher-centered can lead to low interest and motivation in STEM (Krapp, 1999). Bransford et al. (2000) asserted that STEM learning environments support student engagement through the facilitation of high cognitive-demand activities with attention to context, students' roles and interactions with the teacher, other students, and the subject matter. When STEM learning focuses primarily on cognitive engagement for getting the right answer, fewer students will feel that their knowledge is valuable for making connections that lead to understanding (Horn, 2012).

Engaging mathematics instruction occurs when teachers use manipulatives, visuals, gestures, and interactions that actively involve and support students' understanding (Boaler, 2016). Similarly, science learning in K-12 settings is envisioned and enacted as "figuring out" and not merely "learning about" such that students learn to interpret and apply scientific knowledge (Krajcik, 2015). Mathematical practices and scientific and engineering practices in the most recent reform documents of these fields have been clearly aligned (Mayes \& Koballa, 2012). This supports our view that effective STEM teaching practices rely on productive discourse and social construction of knowledge. 
Amid these norms of research-based STEM pedagogy, spring 2020 emergency remote teachers were required to implement teaching strategies that were different from those facilitated in traditional face-to-face courses, and for which they had no prior experience. Teachers were challenged to find ways to facilitate STEM student interactions through hands-on group work in an online environment. Creating a supportive and trusting learning environment that encourages and supports flexible thinking, rich discourse, and varied ways of knowing, and student engagement through peer interaction during group work motivates students to share their thinking and bring STEM learning to a broader range of students (Maltese \& Tai, 2010; National Council of Teachers of Mathematics, 2014; NGSS Lead States, 2013).

\section{Theoretical framework}

Theories guiding this study include the bioecological student engagement framework of Bond and Bedenlier (2019) and Academic Communities of Engagement (ACE) framework (Borup et al., 2014; Borup, Graham, et al., 2020; Borup, Jensen, et al., 2020). These frameworks inform the study due to their educational technology contexts. Given the need for K-12 teachers to use educational technologies to support teaching and student learning during COVID-19, student engagement research conducted in relation to educational technology is particularly relevant.

\section{Bioecological student engagement framework}

Bond and Bedenlier's conceptual framework (see Figure 1) places students at the center of a network of interrelated systems. The framework, which was informed by two systemic reviews of educational technology literature (Bond, 2020; Bond et al., 2020), situates technological influences on student engagement at the macro, exo, meso, and microsystem level (Bond \& Bedenlier, 2019). The microsystem level is where teachers, peers, family, technology, curriculum, the school institution, and the curriculum are situated. At the mesosystem level, the social/economic background interacts with the microsystem and the exosystem, which includes factors such as national curriculum, employment, family social networks, institutional policy, and social services. Within the macrosystem, the social and political environment emerge, along with power, politics, culture, history, economics, and digitalization.

\section{Academic communities of engagement}

This study is also informed by the Academic Communities of Engagement (ACE) framework (see Figure 2; Borup et al., 2014; Borup, Graham, et al., 2020; Borup, Jensen, et al., 2020), which encompasses cognitive, affective, and behavioral dimensions of student engagement in online and blended K-12 teaching. The ACE framework limits engagement to "student involvement with academics" to distinguish it from broader forms of student engagement at the "institutional/ school level" (Borup, Graham, et al., 2020, p. 810). Although the model does not include social engagement as a distinct dimension of engagement, the model assumes a "sociocultural view on learning through communities" (Borup, Graham, et al., 2020, p. 824). A central aspect of the ACE framework is that it emphasizes the mediating factors of parental engagement (e.g., Jay et al., 2018; Patall et al., 2008) and learner communities. In that regard, the ACE framework (Borup et al., 2014; Borup, Graham, et al., 2020; Borup, Jensen, et al., 2020) has certain similarities to the microsystem and exosystem of Bond and Bedenlier (2019) Bioecological Model of Influences on Student Engagement in that parents, teachers, peers, and family social networks are involved in the learning of K-12 students in online and blended learning contexts. Teachers providing instruction during COVID-19 may be apt to provide course community support (see Figure 2) given that area of academic engagement is within their locus of control (see Borup, Jensen, et al., 2020). 


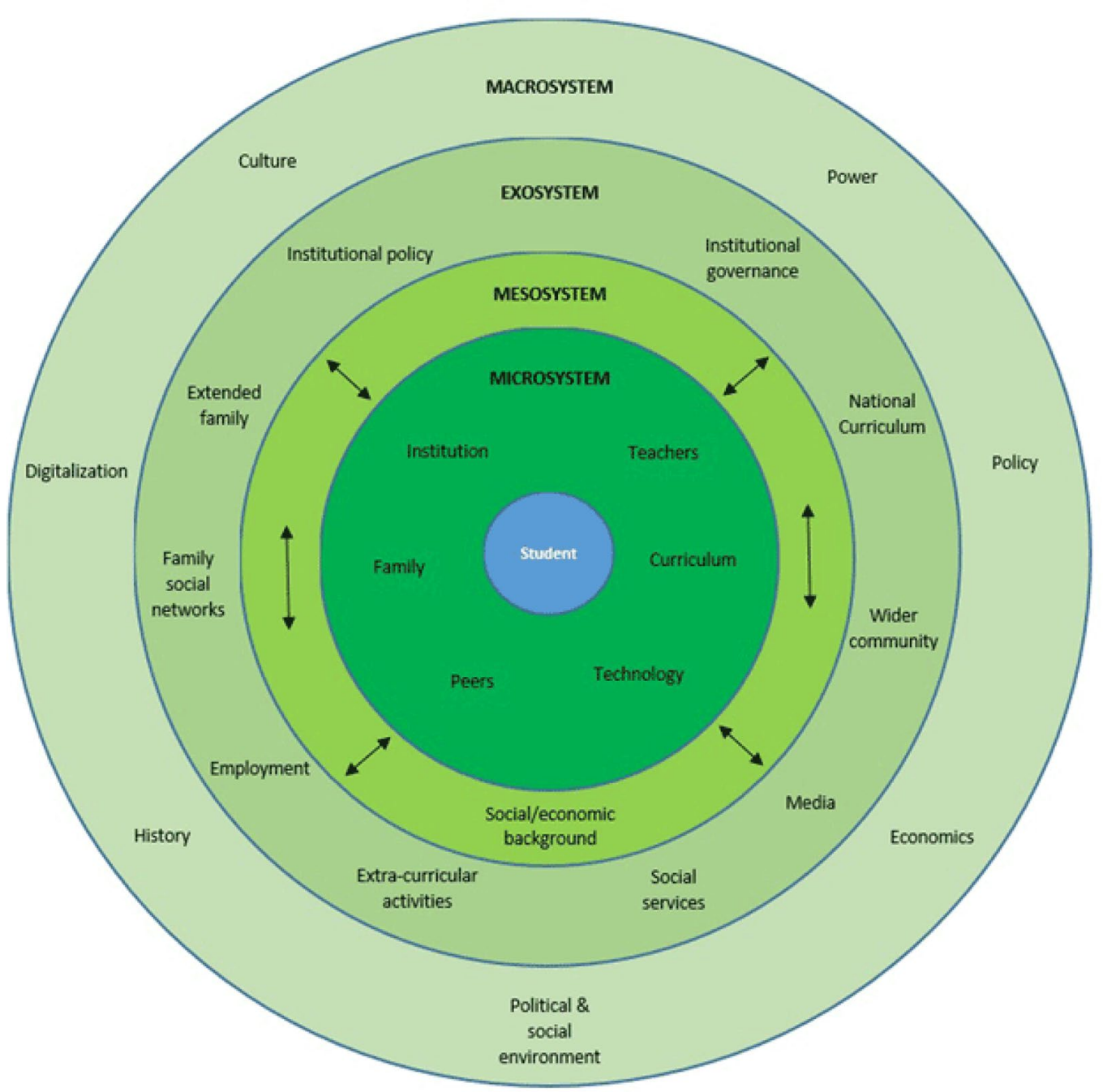

Figure 1. Bond and Bedenlier, (2019) bioecological model of influences on student engagement, based on the work of Bronfenbrenner and Ceci (1994) and Bond (2020).

\section{Trauma-informed teaching and learning principles}

This study also encompasses trauma-informed teaching and learning principles given the traumatic nature of the COVID-19 pandemic (Horesh \& Brown, 2020) and its immense influence on youth mental health (Liang et al., 2020). Since schools often provide trauma-informed care to children, it is essential that schools provide ways to support students' mental health needs (Phelps \& Sperry, 2020). To be trauma-informed, educators need to understand how a traumatic event impacts a student's life at school, at home, and within the community. Educators must then use that understanding to design and provide services that consider the needs and vulnerability of trauma survivors (Carello \& Butler, 2015). Schools that provided remote learning in fall 2020 were dependent upon teachers, to a certain extent, to identify students in need of trauma-informed care. This study incorporated the seven trauma-informed teaching and learning principles presented by Carello (2020) which were informed by the work of the Substance Abuse and Mental Health Services Administration (2014), Fallot and Harris (2009) and Carello and Butler (2015). Carello (2020) designed the following principles in Table 3 with classrooms, departments, schools, and university settings in mind. 


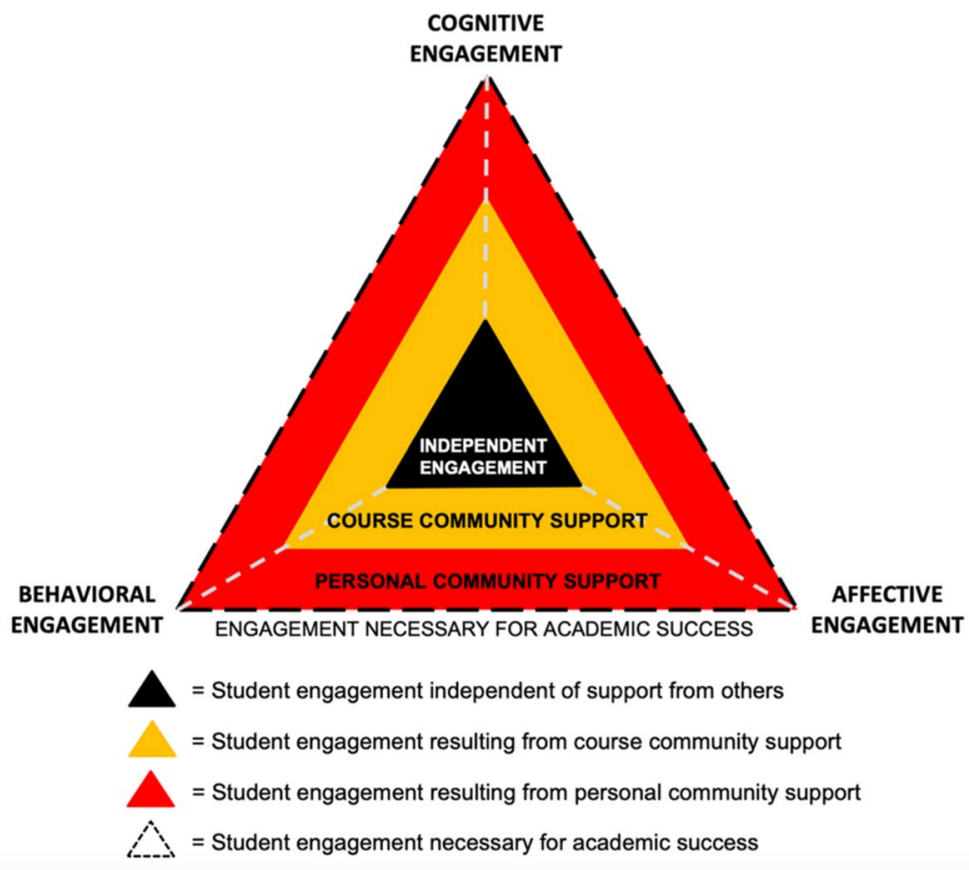

\section{Trauma-Informed Teaching and Learning Principles}

Figure 2. The Academic Communities of Engagement (ACE) framework by Borup et al. (2020).

Table 3. Principles of trauma-informed teaching and learning.

\begin{tabular}{|c|c|}
\hline Principle & Descriptor \\
\hline $\begin{array}{l}\text { Physical, Emotional, Social } \\
\text { and Academic Safety }\end{array}$ & $\begin{array}{l}\text { Efforts are made to create an atmosphere that is respectful of the need for safety, } \\
\text { respect, and acceptance for in both individual and group interactions, including } \\
\text { feeling safe to make and learn from mistakes. }\end{array}$ \\
\hline $\begin{array}{l}\text { Trustworthiness and } \\
\text { Transparency } \\
\text { Support and Connection }\end{array}$ & $\begin{array}{l}\text { Trust and transparency are enhanced by making expectations clear, ensuring consistency } \\
\text { in practice, maintaining appropriate boundaries, and minimizing disappointment. } \\
\text { Individuals and groups are connected with appropriate peer and professional resources } \\
\text { to help them succeed academically, personally, and professionally. }\end{array}$ \\
\hline $\begin{array}{l}\text { Collaboration and } \\
\text { Mutuality }\end{array}$ & $\begin{array}{l}\text { Opportunities exist to provide input, share power, and make decisions. Individuals and } \\
\text { groups act as allies rather than as adversaries to reach common goals. }\end{array}$ \\
\hline $\begin{array}{l}\text { Empowerment, Voice and } \\
\text { Choice }\end{array}$ & $\begin{array}{l}\text { Individuals and groups are empowered to make choices and to develop confidence and } \\
\text { competence. }\end{array}$ \\
\hline Social Justice & $\begin{array}{l}\text { Individuals and groups strive to be aware of and responsive to forms of privilege and } \\
\text { oppression in order to respect one another's diverse experiences and identities. }\end{array}$ \\
\hline $\begin{array}{l}\text { Resilience, Growth and } \\
\text { Change }\end{array}$ & $\begin{array}{l}\text { Strengths and resilience are emphasized over deficiencies and pathology. Feedback is } \\
\text { provided to convey optimism and to facilitate growth and change. }\end{array}$ \\
\hline
\end{tabular}

Adapted from Carello, 2020 Trauma-Informed Teaching \& Learning Principles handout.

\section{Research questions}

The research questions examined within this study include:

1. What were secondary STEM teachers' perceptions of student engagement in their courses in spring 2020 before and during COVID-19 emergency remote teaching?

2. What learner engagement indicators did secondary STEM teachers plan to promote in fall 2020 and how?

3. What principles of trauma-informed teaching did secondary STEM teachers plan to promote in fall 2020 and how? 


\section{Methods \\ Overview}

Because this study is part of a longitudinal study examining a contemporary phenomenon (how STEM teachers engage their students during the COVID-19 pandemic), the researchers employed a single case study design with embedded units of analysis in order to address the research questions (Yin, 2018). In this study, the "case" is a small group of early career STEM teachers who experienced a series of workshops designed to help them engage their students in remote or blended learning during the 2020-21 academic year. The embedded units of analysis were each teacher. Their participation in the study was voluntary, and Institutional Review Board approval was granted prior to data collection. During the first PD session, the researchers discussed the purpose of the study, described data collection procedures, and distributed digital copies of the consent form via participants' emails using DocuSign. All workshop participants consented to participate and were assigned a pseudonym.

\section{Participants and context}

Eleven STEM Teaching Fellows of the Institute of Citizens and Scholars (Citizens and Scholars), formerly Woodrow Wilson National Fellowship Foundation, received an online five-week summer PD opportunity during COVID-19 summer planning. Citizens and Scholars enables individuals with STEM backgrounds to receive a graduate degree in STEM education, classroom experiences, and ongoing mentoring. As part of the program, the Fellows make a three-year commitment to teach in high-need secondary schools in STEM subjects for which they are qualified. The eleven Fellows who volunteered for the summer PD were in the process of completing their three-year commitment, having finished their first, second, or third year of teaching during the 2019-2020 academic term (see Table 4).

The intent of the PD was to support the participants' cognitive, affective, and social needs (see Trust et al., 2020) and to provide them with training and support that helped them meet their professional goals for online and blended teaching (Trust \& Horrocks, 2017). Three full-time faculty members from three different content areas (instructional technology, mathematics education, science education) directed the PD situating this study.

Prior to the PD sessions, the Fellows completed a 23-question needs analysis survey to help shape the focus of the online PD sessions. Results from the survey indicated that although the Fellows felt prepared to teach online, the aspects of teaching they sought to improve involved student engagement strategies (see Table 4). According to survey results, seven of out 11 participants (64\%) strongly disagreed with the statement, "During the school closure of Spring 2020, I was able to sustain student collaborative groupwork via remote instruction" with two participants somewhat disagreeing with the statement. Although the Fellows indicated that they regularly facilitated collaborative learning in face-to-face settings, once their instruction moved online, collaborative learning ceased for all but one Fellow. Table 4 provides additional insights into the challenges that participants faced during COVID-19 teaching and learning.

Given the desire of the Fellows to focus on learner engagement, the PD focused on dimensions of learner engagement within online and blended learning contexts (Bond \& Bedenlier, 2019; Fredricks et al., 2004), with an intentional emphasis on course community support (Borup, Graham, et al., 2020; Borup, Jensen, et al., 2020). Additionally, although not explicitly requested by the Fellows, principles of trauma-informed teaching were introduced (Carello, 2020). One-hour weekly synchronous sessions, hosted in Microsoft Teams, integrated interactive online learning strategies (e.g., breakout rooms, large group formative assessments, polls, collaborative documents) to support collaboration around the participants' prior experiences and personalized learning goals.

The synchronous PD sessions incorporated small breakout groups to provide the teacher participants with time and space to share effective learner engagement strategies. An additional purpose of the breakout rooms was to model collaborative activities when teaching synchronously. 


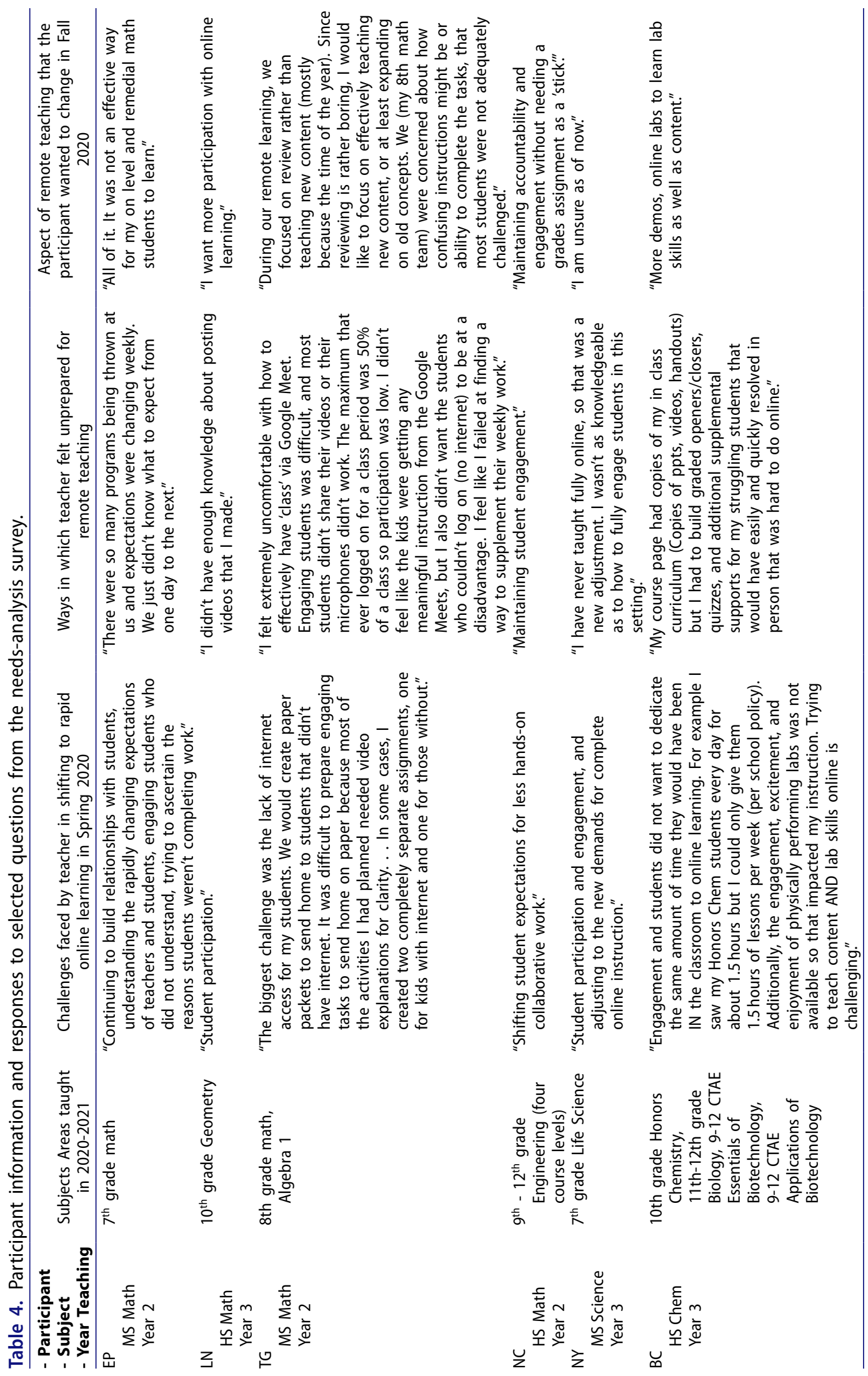




\begin{tabular}{|c|c|c|c|c|}
\hline 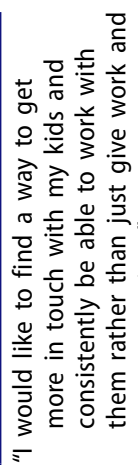 & & 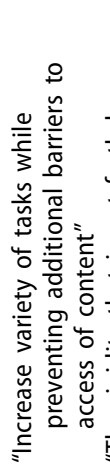 & 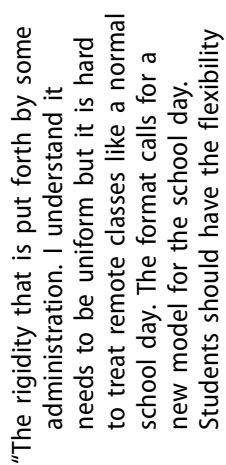 & 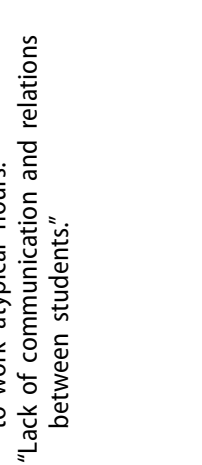 \\
\hline 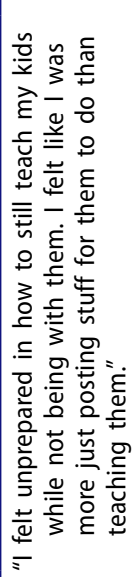 & 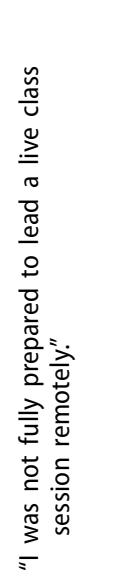 & 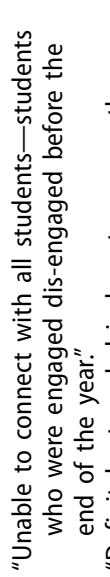 & 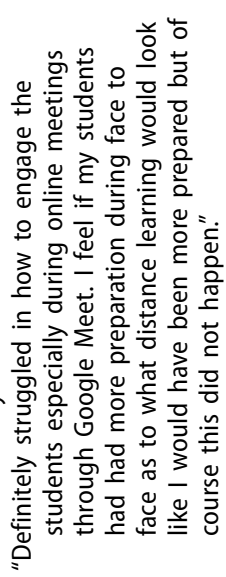 & 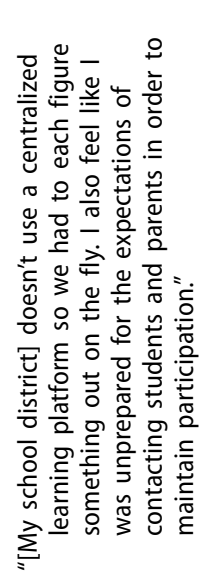 \\
\hline 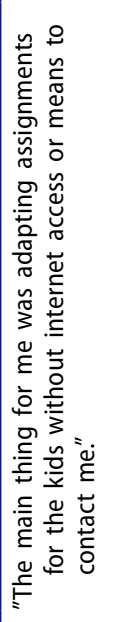 & 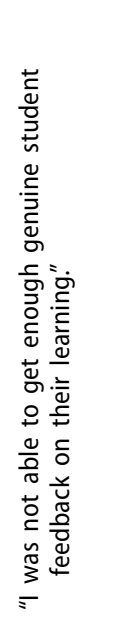 & 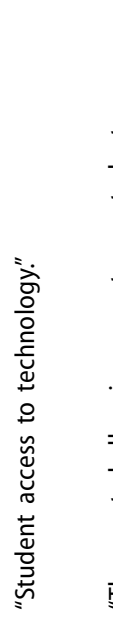 & 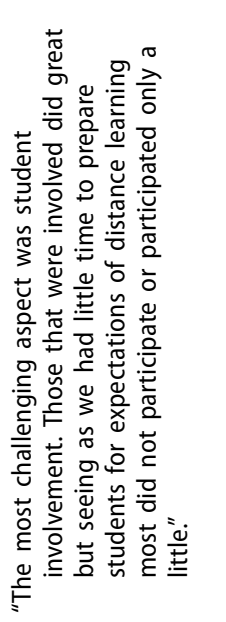 & 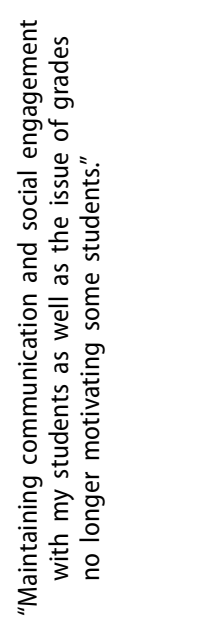 \\
\hline 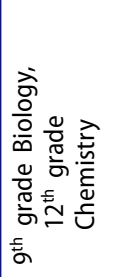 & 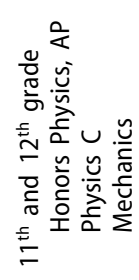 & & 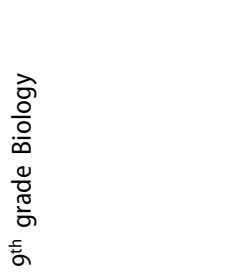 & 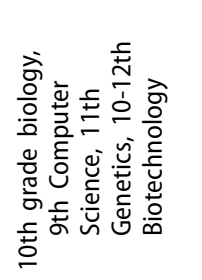 \\
\hline 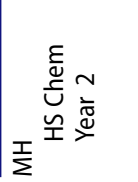 & 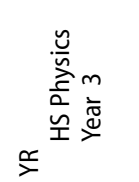 & 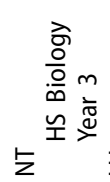 & 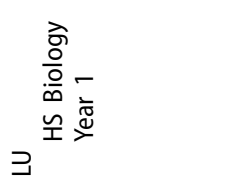 & 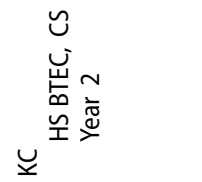 \\
\hline
\end{tabular}


Asynchronous learning activities focused on reflection and project planning using tools introduced during the synchronous sessions, including theoretical readings, asynchronous discussions, project planning, and project development work. The design of asynchronous activities modeled ways that the Fellows could engage learners in their own classrooms (e.g., facilitating asynchronous discussions through Slack or Microsoft Teams, sharing project updates within collaborative documents, annotating readings via Hypothes.is). Overall, the Fellows completed an additional five to ten hours of work outside of scheduled synchronous sessions.

To ensure that the PD met the individual needs of each teacher, a framework of personalized learning (Lokey-Vega \& Stephens, 2019) guided the overarching purpose of the PD experience. The central PD goal was to introduce the Fellows to the dimensions of student engagement, to encourage the Fellows to use those theories to inform their online teaching practice in fall 2020, and to support the Fellows in the design and creation of a project for fall 2020 implementation. The goal was to support the Fellows' agency, as is congruent with recommended best practice for cohort-based PD (Trust \& Horrocks, 2017).

To support the Fellows in the creation of their projects, each Fellow met one-on-one with an instructional technology faculty member (first author) for one-hour co-planning sessions in the second week of the PD experience. The faculty member introduced specific content-based instructional tools and strategies that would support the Fellows in meeting their outlined goals. The Fellows were specifically asked to consider dimensions of learner engagement in the design of their project, as they had read and collaboratively annotated the articles by Bond and Bedenlier (2019) and Borup, Jensen, et al. (2020). For replication purposes, the structure and organization of the PD are synthesized in Appendix A.

\section{Data collection}

Data collected during summer 2020 included a needs analysis survey distributed via Qualtrics, co-planning sessions, teacher artifacts, video recordings of synchronous sessions, and individual exit interviews with all participants. Teacher artifacts included initial reflections on spring 2020 teaching (see Appendix B), workshop assignments (e.g., mid-point project plans), and presentations created by participants during the PD workshops. Survey data informed the design and content of the workshop and provided information about the participants' prior experiences with student engagement before and after the onset of COVID-19 in spring 2020. Interviews were conducted using Zoom video conferencing software, recorded, and transcribed with Otter.ai. The interview protocol asked teacher participants to describe how they engaged learners during the abrupt change to emergency online teaching, and what they would prefer to do differently in the upcoming school year (see Appendix C). Artifacts were examined to identify the dimensions of student engagement (behavioral, cognitive, affective, social) that teachers prioritized during COVID-19 teaching and learning as well as the principles of trauma-informed teaching.

\section{Data analysis}

The first author created a theory-driven codebook (DeCuir-Gunby et al., 2011). Codes were derived from Bond et al.s (2020) indicators of student engagement (see Table 1) and disengagement (see Table 2) and principles of trauma-informed teaching (see Table 3) curated by Carello (2020). Given that the ACE framework (Borup, Graham, et al., 2020) included student dimensions of affective, behavioral, and cognitive academic engagement with a sociocultural view of learning, the overlap of the ACE framework on aspects of Bond et al.s (2020) Bioecological Model of Influences on Student Engagement (see Figure 1) did not require a separate coding structure as affective, behavioral, cognitive, and social indicators were accounted for. Prior to data analysis, the research team met to discuss the codebook, agree upon definitions and receive training from the first author on coding the data. The finalized codebook and data were imported into Atlas. ti Cloud. 
The second, third and fourth authors divided the data and analyzed their assigned participant's data in chronological order: (a) pre-reflection; (b) project presentation transcript and workshop assignments (e.g., mid-point project updates, final presentations with instructional materials); and (d) exit interview transcript. Formative workshop activities (e.g., Spiral responses) and one-on-one coaching sessions were not coded. Once the initial coding was complete, the research team met to discuss the patterns in the data across participants. Initial findings warranted a revision to the codebook to include social engagement indicators (Fredricks, Wang, et al., 2016). The first author then returned to the data in totality to re-code for social engagement and to check for reliability across all data segments coded by the other researchers. The research team met again to discuss discrepancies in the data analysis and come to agreement before finalizing their interpretations of the data. The first author created an audit trail to document data collection and analysis decisions. Verification techniques to ensure trustworthiness included reliability checking, triangulation of all data sources, member checking and seeking out disconfirming evidence.

\section{Findings}

In the sections below, we detail the findings relative to each of the three research questions. Given the qualitative nature of the findings, we present the data alongside interpretations of the findings to aid in reader understanding given the nature of the case.

\section{RQ1. What were secondary STEM teachers' perceptions of student engagement in their courses in spring 2020 before and during COVID-19?}

To answer the first research question, we coded and analyzed all survey data and initial reflections, both of which were collected after the 2019-2020 school year ended and before participants engaged in any summer PD sessions. The survey provided an opportunity for the participants to share the pedagogical challenges they faced during the initial months of the pandemic, and the desire to enhance their teaching practices in preparation for fall 2020. Initial reflection prompts (see Appendix B) enabled the participants to more deeply reflect on that time period to make meaning of their experiences with student engagement (Brookfield, 2017).

\section{RQ1 findings from the survey data}

In the survey, when asked about their challenges associated with rapid online learning, all participants identified students' lack of online interaction and engagement as problematic. Select participants cited students' lack of access to the internet, and the lack of a centralized learning platform as barriers to promoting learner engagement. The student engagement challenge was compounded by the state-wide "do no harm" grading policy which did not allow students' overall course grade to drop from where it existed prior to the onset of emergency remote teaching.

All participants reported confidence in using technology (e.g., Google Classroom, Remind, Schoology, class blogs) to communicate with and engage students in learning during face-to-face instruction. When asked what technology tools had been/would continue to be essential for promoting student engagement in fall 2020 learning, the participants overwhelmingly identified a centralized online learning platform that enabled easy access for student interaction, tools to facilitate a flipped classroom, and strategies to assist with adapting face-to-face engagement activities to an online environment as essential for effective remote teaching.

\section{RQ1 findings from the initial reflection data}

The initial reflection prompts (see Appendix A) asked participants to describe their teaching experiences before and after COVID-19 school closures, but to a greater extent and in more 
detail than the survey. Coding of the initial reflections generated patterns across the indicators within cognitive, affective, behavioral, and social student engagement domains (Bond et al., 2020). Codes that emerged in high frequency from data analyzed across all participants are italicized in the descriptions of the findings below.

Participant descriptions of learner engagement during face-to-face teaching prior to the COVID-19 pandemic focused overwhelmingly on cognitive, behavioral, and social engagement indicators with less emphasis on affective indicators (see Table 5). During face-to-face teaching, participants most frequently perceived cognitive engagement as (a) critical thinking and deep learning through problem-solving; (b) self-regulation enhanced by goal setting; (c) integrating ideas/inquiry-based observations during science labs; and (d) the use of sophisticated learning strategies that enables the exploration of concepts and collaboration among peers. Additionally, participants identified the behavioral indicator participation/involvement as critical to promoting understanding, responsibility, and accountability. Both science and mathematics respondents identified participation most frequently as a behavioral indicator of learner engagement in the classroom. For example, a mathematics teacher participant described participation as, "doing, rather than just watching" (TG, Initial Reflection), as well as "participating with your group and not relying only on other members" (TG, Initial Reflection). A science teacher participant stated, "engaged students complete all of the assignments on time and put in more work when it is required to master content" (YR, Initial Reflection). Similarly, a mathematics teacher participant stated "...to show they understand the material, the student is completing their assignments" (LN, Initial Reflection) as evidence of student engagement. With respect to social engagement, participants identified (a) learning from peers and (b) trying to understand others' ideas as important practices to supporting student engagement and learning.

The teacher participants also described their experiences with student disengagement. In the initial reflection data, participants cited behavioral disengagement indicators (see Table 6), more than affective, cognitive, and social indicators noted prior to the pandemic. Participants cited face-to-face behavioral disengagement indicators as distracted, associated with "students on their phones" (BC, Initial Reflection), "having issues with note-taking" (EP, Initial Reflection), and "talking to other students during lecture" (KD, Initial Reflection) as described by both science and mathematics teacher participants. Participants' pre-COVID-19 perceptions of affective disengagement included indicators such as boredom during the facilitation of in class assignments and students becoming overwhelmed due to "the amount of change in such a short time" (BC, initial reflection). One mathematics teacher participant stated, "if I did the same assignment every day, students would get bored, so it's important to switch up the assignments to promote engagement" (LN, Initial Reflection). Before COVID-19, students had greater opportunity to engage in discourse during lessons and groupwork. A science teacher participant indicated that "students talking to each other for long periods of time about topics not related to class" as an example of student disengagement (KD, Initial Reflection).

Table 5. Initial reflection total engagement indicators.

\begin{tabular}{lccc}
\hline $\begin{array}{l}\text { Cognitive } \\
\text { Engagement }\end{array}$ & $\begin{array}{c}\text { Behavioral } \\
\text { Engagement }\end{array}$ & $\begin{array}{c}\text { Affective } \\
\text { Engagement }\end{array}$ & $\begin{array}{c}\text { Social } \\
\text { Engagement }\end{array}$ \\
\hline $\begin{array}{l}\text { Face to Face Teaching } \\
68\end{array}$ & 41 & 18 & 33 \\
$\begin{array}{l}\text { Remote Teaching } \\
6\end{array}$ & 33 & 4 & 12 \\
\hline
\end{tabular}

Table 6. Initial reflection total disengagement indicators.

\begin{tabular}{lccc}
\hline Cognitive Disengagement & $\begin{array}{c}\text { Behavioral } \\
\text { Disengagement }\end{array}$ & $\begin{array}{c}\text { Affective } \\
\text { Disengagement }\end{array}$ & $\begin{array}{c}\text { Social } \\
\text { Disengagement }\end{array}$ \\
\hline Face to Face Teaching & 20 & 9 & 2 \\
7 & 19 & 5 & 4 \\
12 & 19 & 5 & 4 \\
\hline
\end{tabular}


During remote teaching in Spring 2020, participants identified student disengagement indicators most frequently as cognitive and behavioral. For example, with respect to cognitive disengagement students lacked interest or enthusiasm (apathy) and helplessness associated with technology access. During remote teaching, some students were absent or unprepared because, through no fault of their own, they experienced issues with attending class remotely due to a lack of technology or internet access.

\section{RQ2. What learner engagement indicators do secondary STEM teachers intend to promote in fall 2020 and how?}

Results from research question two were derived from coded responses of participants' initial written reflections (questions 6 and 7 specifically, see Appendix A), project presentation, and exit interview transcripts (see Table 7). These data represent participants' perspectives immediately before and after the onset of the summer PD workshop as they envisioned their teaching practice for the upcoming academic year. Participant comments, relative to student engagement, were generally balanced across the cognitive, affective, behavioral, and social engagement domains with 105, 107, 119, and 106 codes applied, respectively.

Although the most frequent use of codes applied to these data for all participants were those relating to behavioral engagement, the diversity of code use in this dimension was the highest, resulting in few strong patterns of behavioral engagement. The most frequent behavioral engagement indicators were student participation during rapid online learning, and to a lesser degree, student homework completion and attendance, though less prominent than some indicators cited for cognitive engagement. A marked increase in affective engagement indicators emerged from the coding of these project presentation and exit interview data in comparison to the pre-PD reflection data. This is not a surprise given that the summer workshop focused on the Academic Communities of Engagement framework (Borup, Graham, et al., 2020) and an overview of the cognitive, affective, and behavioral dimensions for facilitating student engagement with educational technology (Bond \& Bedenlier, 2019).

Table 7. Most frequent engagement indicators by data source.

\begin{tabular}{|c|c|c|c|}
\hline Cognitive Indicator & $\begin{array}{c}\text { Initial } \\
\text { Reflection }\end{array}$ & $\begin{array}{c}\text { Project } \\
\text { Presentation }\end{array}$ & $\begin{array}{c}\text { Exit } \\
\text { Interview }\end{array}$ \\
\hline Critical thinking & 2 & 5 & 13 \\
\hline Integrating ideas & 2 & 7 & 9 \\
\hline Sophisticated strategies & 1 & 0 & 11 \\
\hline Deep learning & 2 & 4 & 5 \\
\hline Self-regulation & 0 & 7 & 7 \\
\hline \multirow{2}{*}{ Affective Indicator } & Initial & Project & Exit \\
\hline & Reflection & Presentation & Interview \\
\hline Sense of connectedness & 2 & 14 & 6 \\
\hline Sense of belonging & 1 & 9 & 9 \\
\hline Sees relevance & 0 & 4 & 7 \\
\hline Interest & 1 & 5 & 5 \\
\hline \multirow[t]{2}{*}{ Behavioral Indicator } & Initial & Project & Exit \\
\hline & Reflection & Presentation & Interview \\
\hline Participation & 8 & 7 & 24 \\
\hline Attendance & 1 & 1 & 9 \\
\hline Homework Completion & 3 & 1 & 7 \\
\hline Access Course Material & 2 & 6 & 6 \\
\hline \multirow[t]{2}{*}{ Social Indicator } & Initial & Project & Exit \\
\hline & Reflection & Presentation & Interview \\
\hline Interaction & 0 & 14 & 23 \\
\hline Learning from peers & 7 & 10 & 12 \\
\hline Positive interactions & 1 & 6 & 7 \\
\hline Teaching self and peers & 0 & 4 & 5 \\
\hline Understand others' ideas & 2 & 2 & 6 \\
\hline
\end{tabular}




\section{Cognitive engagement indicators}

Cognitive engagement indicators relating to critical thinking included project-based instruction, guiding student metacognition, students teaching each other how to solve mathematics problems, expanding the array of "real-world" examples of mathematical and scientific phenomena, increasing student choice in the extend-phase of scientific inquiry, and identification of online simulations for use by science students. Applying learning to relevant aspects of students' out-of-school lives most often characterized participants' discussion of critical thinking. For example, a mathematics teacher who asserted that "geometry is everywhere around us" (LN, Exit Interview), developed a "parallel city" project in which students analyzed angles of parallel lines cut by transversals, applying academic vocabulary to the design of a road system. A science teacher made plans during the summer PD workshop to engage each of her freshman environmental science students in a long-term citizen science project, conducted as an at-home nature study. Integrating ideas was the other cognitive engagement indicator frequently referenced in participants' discussion of their plans for fall 2020. This was exemplified by participating teachers' discussion of student use of technology to support increased autonomy during active learning, while also providing formative assessment data to enhance teachers' feedback to students. Examples of this included student use of Nearpod and polling tools for online formative assessment, Screencastify to report progress, student use of Desmos for graphical analysis, and student use of Spiral to report potential problems with engineering tasks.

\section{Affective engagement indicators}

When coding for indicators of affective engagement, the participating teachers' post-PD project presentation and exit interview comments indicated a dramatic increase in references to students' sense of connectedness to school and sense of belonging. In contrast to the initial reflections on spring 2020 teaching, which generated very few references to these affective indicators, each of the eleven participants discussed fall 2020 teaching in relation to student connection and belonging. Although the planned projects varied based on school context factors, all teacher participants attended to class community-building in their designs. Participants echoed the challenge of building rapport and class-community with new students during fall 2020 semester. The expectation of online or hybrid instruction led participants to rethink their typical relationship-building activities at the onset of a semester, adapting them to virtual modality, as explained by one middle school science teacher participant:

I transitioned the "all about me" [learning activity] to a Google Form. I usually keep them on paper, and I keep them in a folder on my desk. I also did a Flipgrid activity about how Spring digital learning went for them. So they can give me a video in like a minute 30 seconds and tell me what they liked about it, what they didn't, and like what could have been improved. I do have them set up signatures on their emails, because I have them send emails for the missing work or if they're collaborating with their classmates. So we do an email setup. I turned the email setup directions [previously completed face-to-face] into a Screencastify where I explained how to do that. I also have kids create a Playlist with their favorite songs and I make a class Playlist so they can use any of their Music platforms to make that and send it to me on Schoology. So I usually do this during the first two to three weeks of school when we start building relationships (NY, Project Presentation).

A common view held by participants included fostering students' sense of belonging through collaborative work to enable student support in mathematical problem solving or science inquiry learning. The teacher participants emphasized how academic group work fosters a sense of connection and belonging. One science teacher stated, "I want to increase the feelings of connectedness between students in the class, knowing that we're all contributing to science in some way" (KC, Project Presentation). Another science teacher who typically "jumps right into content" instead of doing "the typical getting to know you stuff" decided to use Flipgrid student introductions during the first week of fall 2020 classes, explaining "the video introductions, and that whole process..., is really for the affective engagement to try to get students to essentially be friends and learn about each other" (YR, Exit Interview). This same teacher planned to use 
Flipgrid for student presentations of science concepts to peers to "provide a review for other students, because then you have the sense of belonging and you have the feeling of being appreciated and all those things" (YR, Exit Interview). A mathematics teacher participant asserted that "having relationships with your students, and students having relationships with their peers affects [learning]. So definitely, now working from home, I think that affects how well students will learn and be engaged" (LN, Exit Interview). Participating teachers' plans to "check-in" with individual students consistently was an intention of many participants, focusing on student wellness and/or project work.

As instructors in the summer PD workshop, we had an impression that was subsequently borne out in the data, that the challenges imposed by COVID-19 had shaped our participants toward teaching practices that were more balanced regarding increased attention to the affective domain, as opposed to their spring 2020 emphasis of cognitive and behavioral engagement. A participant typified this revised focus, explaining that her online science lessons at the start of the fall 2020 semester would involve:

\footnotetext{
...for the first ten minutes...like icebreakers, get to know you and "How's your day going?" talk. I'm thinking more about building those relationships that you typically build in the classroom, but since we're now online, we have to make a more concentrated effort and intentional effort to build those relationships, before going into content, and we are leaning more on formative than summative assessments, through the virtual labs (BC, Exit Interview).
}

Common to all participants' expectation of fall 2020 online teaching was the capacity of their school's virtual learning platform to manage and guide students in small group cooperative learning, as depicted by NT (Exit Interview), "My intent is to incorporate Teams and the breakout sessions in the synchronous activities that we do going forward. So that's the first, I guess, strategy for trying to build a little sense of community."

\section{Behavioral engagement indicators}

The behavioral engagement indicators found in the post-PD data included codes depicting basic expectations of student action, those being (in order of frequency) participation, attendance, homework completion, and accessing course materials. These behavioral indicators were typically representative of participant comments describing a starting point for student engagement or the frustration of students being absent or unwilling to take part in synchronous instruction. Some participants referenced student discourse about the STEM subject matter as a more significant indicator. Apart from two teachers who taught upper-level/AP high school courses, the other nine participants described low attendance and shallow engagement during online instruction from March to May 2020. Considering the start of the fall 2020 academic year, all participants articulated a vision of student engagement that was much more interactive and collaborative than they were able to achieve during the spring rapid online learning after the summer PD. As a science teacher noted:

I want to really avoid what I did in spring, where I would just sort of tell them what they need to do and then they go through a list of tasks. To increase engagement, I want to take the time to plan and provide space for kids to really talk to each other (NT, Exit Interview).

Developing ways to increase student-talk (e.g., asking questions, engaging in subject-specific peer dialogue) was a common focus for the participants for fall 2020 teaching. To achieve this goal, teacher participants sought to establish a clear and predictable online learning environment with multiple ways for students to communicate online.

\section{Social engagement indicators}

Coding participating teachers' post-PD project presentation and exit interviews for indicators of social engagement revealed a distinct increase in references to interaction, while no initial 
reflections received this code. In their post-PD project presentations, most participants mentioned specific technology tools (e.g., Flipgrid, Google Forms, Google Jamboard, Nearpod, Padlet, Screencastify, Spiral, Microsoft Teams) as planned support for student interaction. Participants completed the summer PD with increased efficacy for supporting collaborative interactions in an online learning environment. For example, a science teacher explained:

I am more comfortable with, number one, providing a space for the kids to interact with each other, as well as providing the framework for the course that's more flexible, so even if kids can't meet me at 9:15 every day, I will have the content and other things available to the so they can connect some different ways (NT, Exit Interview).

Integration of educational technology was more frequently represented in the social engagement indicator coded as learning from peers, in which participants emphasized the importance of virtual "rooms" for guiding students to work in collaborative groups, and student use of Google Jamboard, Slack, and Flipgrid for reporting-out their thinking to the whole class. Peer learning was most often represented as students sharing meaningful work products to benefit the class learning community. A chemistry teacher's periodic trends project, adapted for virtual instruction during the summer PD, typifies peer learning through students' depiction of periodicity applied to analogous personal interests.

\section{RQ3. What principles of trauma-informed teaching do secondary STEM teachers intend to promote in fall 2020 and how?}

Data analysis indicated that participants made intentional plans to infuse trauma-informed teaching principles (Carello, 2020) into their instruction and learning contexts. Six of the seven principles were identified across the participants' exit interview transcripts, project presentation transcripts and presentation slides: (a) physical, emotional, social and academic safety; (b) trustworthiness and transparency; (c) support and connection; (d) collaboration and mutuality; (e) empowerment, voice and choice; and (f) social justice. The remaining principle, (g) resilience, growth and change, was not consistently represented in the data (see Table 8 for code frequency counts).

\section{Physical, emotional, social, and academic safety}

Providing an academic environment in which students feel physically and emotionally safe, respected and accepted individually and as a group, and free to make and learn from mistakes is a fundamental pre-condition to successfully educating students who are experiencing the trauma (Carello, 2020; Carello \& Butler, 2015), especially while attending school during a pandemic. Participants in this study identified several ways in which they intended to build a safe learning environment for their students. Although participants were unsure exactly how the school year would begin (e.g., online, blended), they wanted to "build rapport with the students" (BC, Exit Interview) and attend to students' emotional and social safety. NY's statement during her final presentation captured the group's sentiment, "With the uncertainty of how we would return back to school, I wanted to work to digitize most of my beginning of the year activities in case we started off with virtual learning for our students." To this end, participants made

Table 8. Most frequent trauma-informed teaching principles by data source.

\begin{tabular}{lccc}
\hline Trauma-informed Teaching Principle & Initial Reflection & Project Presentation & Exit Interview \\
\hline Support and connection & 26 & 9 & 44 \\
Physical, emotional, social, and academic safety & 3 & 11 & 22 \\
Social justice & 0 & 7 & 17 \\
Empowerment, voice, and choice & 10 & 16 & 15 \\
Trustworthiness and transparency & 1 & 19 & 15 \\
Collaboration and mutuality & 11 & 7 & 15 \\
Resilience, growth, and change & 0 & 2 & 4 \\
\hline
\end{tabular}


plans to get to know their students through regular one-on-one virtual conferences, icebreaker activities, teacher video introductions, and interest questionnaires. Other ideas included providing safe spaces for student to interact with each other in online break-out rooms, student introductions using FlipGrid, implementing social-emotional learning activities, and establishing online netiquette rules. Academic safety was also important to participants. TG's statement captures what many of the other participants wanted to do: “... provide a learning environment where [students] can learn together, ... building collaboration, and ... have a safe environment where they feel okay to make mistakes" (Exit Interview). Participants intended to accomplish this via non-graded assignments, formative feedback during project "check-ins," and creating ways for students to experience small successes early in the school year to build their confidence.

\section{Trustworthiness and transparency}

Establishing clear and consistent expectations for assignments and grading policies as well as providing a structure for an online or blended course is key to establishing students' trust and minimizing disappointment or confusion (Carello, 2020). Fostering a sense of belonging through collaborative work that guides peer support in mathematical problem solving or science inquiry learning characterized a common view of how academic group work fosters student connection and belonging to a class community. Given the shift to online instruction at the start of the pandemic, the participants' wanted to be "remote learning ready... this year ... making sure that there's consistency and structure so that the students know day one, no matter what, there's going to be a little bit more consistency" (NC, Exit Interview). Some of the strategies they sought to implement included re-organizing the online layout of their of courses to make assignment directions and due dates easy to locate, establishing deadlines and assignment expectations at the beginning of the semester, and maintaining consistency with assignment scope and quantity to avoid overwhelming the students. Other strategies included having students engage in weekly warm-up activities and create end-of-unit video journals to summarize what they learned.

\section{Support and connection}

Data from participants' initial reflection revealed that all intuitively used the support and connection principle of trauma-informed teaching during COVID-19 remote learning. This included providing students with learning support, helping students connect with peers, and communicating with students and parents. The participants attributed their ability to do this based on the relationships they established with their students prior to rapid online learning. Nevertheless, the teachers did not feel entirely successful as more than half of their students stopped attending online class sessions before the 2019-2020 school year ended. Thus, participants were concerned that it would be more challenging in fall 2020 to establish a learning community where students felt connected if they returned to school online. The data analysis indicated that during the 2020 fall semester, the participants sought to provide trauma-informed teaching more than any other principle. Plans included establishing student-to-student support systems in which students could ask questions and obtain help from peers while working on group projects, using Slack for asynchronous communication, providing contact information to parents, encouraging community and family engagement with students (Borup, Jensen, et al., 2020), establishing online office hours, and meeting one-on-one with students to discuss existing and needed support structures at home and school.

\section{Collaboration and mutuality}

The data indicated that participants had a strong desire to promote student collaborations in fall 2020, something that had been lacking during remote learning in the spring. They planned to use technologies (e.g., Google Jamboard, Google Meet, Slack, MS Teams) to facilitate group work, collaborative projects, and student-led discussions. For example, TG was planning to use 
Google Jamboard, an interactive whiteboard, with her $8^{\text {th }}$ grade mathematics students so they could collaborate on problem-solving tasks. Additionally, participants planned ways to advance mutuality. One strategy was gathering course input from students, which ranged from generating semester goals like "... what would be a great science classroom" (NT, Exit Interview) or using feedback polls to garner "... constructive criticism to improve the course" (BC, Exit Interview). Another involved using jokes, quotes, memes, or music supplied by the students to create a classroom culture that would promote engagement.

\section{Empowerment, voice and choice}

To mitigate the loss of control and uncertainty that students felt due to COVID-19 school closures, teacher participants wanted to empower their students to make choices, develop confidence, and increase their competence by giving their students more control over goal setting, project choice, assignment options, and technology use to support their learning. For example, EP decided to create individual student notebooks in Microsoft Teams so that students could use assessment data to specify mathematics goals, create an action plan, and self-evaluate their progress. KC created a semester-long service-learning assignment where students would choose an environmental Citizen Science project, collect and analyze data, share their project, and create an artifact to apply their learning. Other cited strategies included choice boards and peer-teaching to encourage academic growth.

\section{Social justice}

Six of the 11 participants indicated that they sought to incorporate activities related to social issues including Black Lives Matter and COVID-19. Several science teachers planned to connect COVID-19 to their science content and the "disproportionate impacts of COVID in the black community and the Latinx community" (LU, Exit Interview). BC intended to engage students in conversations about "minority science inventors and contributors that get left out of the textbooks" (Exit Interview). Two participants (NT and KC) planned to introduce projects based on environmental and social justice. Both math and science teachers discussed how best to serve their students, giving them space to talk about what was happening around them. NY noted that "in light of everything that happened, I think kids need to feel heard in the classroom, especially our black and brown kids" (Exit Interview). The five participants who did not have plans to incorporate activities related to social justice could not figure out how to "fit it into their curriculum" or wanted to emphasize a smooth transition back to school given the likelihood of online learning.

\section{Limitations}

A limitation of this research study is that the engagement indicators put forth by Bond et al. (2020) are constrained to cognitive, affective, and behavioral dimensions of engagement. To create indicators for social engagement, we engaged in collaborative discussion and used Bond et al's (2020) original indicator list to identify which indicators previously categorized within cognitive, affective, or behavioral dimensions fit better as social engagement indicators. We determined the indicators based on our interpretation and used the social engagement survey items from Fredricks, Wang, et al. (2016) to guide our discussion. Despite these measures, it has been argued that "different dimensions of engagement are dependent on each other, interlinked rather than discrete and disconnected" (Kahu, 2013, p. 768). The challenge faced by the authors of this study in coding the data was the potential overlap of indicators of student engagement that could exist in more than one dimension, such as "confidence" (potentially a behavioral and affective code). During the coding process, researchers discussed and collectively reconciled codes that seemed problematic. 


\section{Conclusion}

In this study, we sought to examine how induction secondary STEM teachers planned for online and blended learning that focused on student engagement and responsive instructional practices using trauma-informed teaching and learning principles. In the first research question, we identified secondary STEM teachers' perceptions of student engagement prior to and immediately after the onset of COVID-19 in spring 2020. The themes that emerged from the survey data indicate that while participants were confident in using technology to engage students in learning during face-to-face instruction, they also experienced challenges associated with students' lack of access to technology and the absence of a centralized learning platform to support student interactions with content, peers, and the teacher. Themes that emerged from the initial reflection data indicate that participants primarily emphasized cognitive dimensions of student engagement before COVID-19, followed by attention to behavioral and social indicators. Behavioral disengagement indicators were perceived as barriers to student engagement before and after the onset of COVID-19. During spring 2020 teaching during COVID-19, participants prioritized behavioral engagement, and to a lesser extent social engagement, when facilitating and supporting learning activities.

In the second research question, we identified the learner engagement indicators that the secondary STEM teachers intended to promote in fall 2020. Across the four engagement domains, the noteworthy pattern in the data was the participants' increased focus on social engagement indicators (interaction, learning from peers) and new attention given to affective indicators (sense of connectedness to school, sense of belonging). Participants continued to be concerned about and thus focused on behavioral indicators such as participation and attendance. Likewise, cognitive engagement continued to garner attention with participants targeting the top two indicators of critical thinking and integrating ideas. The synergy of the engagement indicators that participants intended to promote suggests that they developed a renewed vision for student engagement that was more interactive, collaborative and project-based in the upcoming school year.

In the third research question, we identified the principles of trauma-informed teaching that secondary STEM teachers intended to promote in fall 2020. The themes that emerged from an analysis of the exit interviews, project presentations, and presentation slides indicate that, in light of uncertainties resulting from the pandemic, STEM teachers were intentional about infusing trauma-informed principles into their instructional practice. The majority expressed a commitment to social justice and planned to engage students in activities related to social issues. Further, they valued building rapport with students using icebreaker activities, one-on-one virtual conferences, and creating a safe learning environment to connect with students and support student learning and academic success. Infusing trauma-informed practices such as physical, emotional, social and academic safety, provided students with an opportunity to collaborate and learn from each other, and exercise their freedom to learn from mistakes and misconceptions, which fostered students' empowerment and voice as well as their sense of belonging.

Collectively, teachers in this study sought new instructional strategies and approaches to engage effective STEM teaching practices within an online environment. They had to rethink what learning looks like, how to assess it, and how to promote meaningful student engagement and learning during online teaching. While pre-COVID-19 teaching and learning had an emphasis on content and assessments which were associated with cognitive and behavioral indicators, planning for a fall 2020 return with COVID-19 present compelled teachers to consider the importance of connecting content more deeply with the emotional needs of their students.

When teacher participants in this study reflected on their spring 2020 teaching, both in face-to-face and remote contexts, the affective dimension of student engagement was not their central priority. Cognitive dimensions of student engagement were emphasized prior to the COVID-19 pandemic, but once the shutdown occurred in March 2020, behavioral dimensions of engagement took precedence. The participants' positions on student engagement shifted again as they prepared for fall 2020 teaching. Why was this so? The participants noted that they had 
already developed rapport with their students by the time that COVID-19 shut down schools in March 2020. With rapport previously established, the teacher participants could focus on student behavioral engagement indicators via the tools at their disposal (e.g., assignment submissions, LMS analytics, synchronous session attendance). The participants wanted to continue to address curriculum standards, which tend to prioritize cognitive dimensions of learning, but the participants recognized that many of their instructional practices were rooted in social engagement strategies (e.g., partner work, small group discussions) that they questioned how to proceed when emergency remote teaching commenced. The summer 2020 PD experience enabled the teacher participants to receive personalized strategies to support all four dimensions of student engagement. Based on our analysis of the data in this study, the teacher participants prioritized providing their fall 2020 students with opportunities for (a) support and connection (trauma-informed teaching principle); (b) interaction (social engagement indicator); (c) participation (behavior indicator); (d) connection and belonging (affective indicators); and (e) critical thinking and integrating ideas (cognitive indicators).

\section{Discussion and implications}

Given the context of COVID-19, we argue that teacher awareness and action in the affective domain of student engagement is critical during times of trauma. Frick (2020) recently stressed that the affective bonds that teachers and students form are the "most important relationship in education systems that must be nurtured" (p. 701). Educators, therefore, should be particularly attentive to affective dimensions of student engagement during times of trauma (e.g., COVID-19), otherwise other dimensions of engagement may suffer. For example, if teachers emphasize cognitive and social dimensions of engagement (e.g., developing critical thinking skills through peer interactions), but students are absent from class (a behavioral engagement indicator) because they feel overwhelmed (an affective disengagement indicator), then the affective needs of those particular students should be prioritized. In our study, participants' attention to the affective and social dimensions of student engagement increased due to potential for remote learning during fall 2020 and the isolating nature of COVID-19 pandemic. The teachers' actions further support the idea that learning contexts and student engagement within those learning contexts are inextricably linked (see Xie, 2021).

\section{Implications for practice}

The transition to rapid online learning required educators to reexamine their face-to-face instructional practices. The teachers within this study articulated their intent to take action to support affective student engagement and to provide trauma-informed teaching practices in fall 2020, but these actions required targeted resources and support. Although technology tools provide affordances that teachers can use to promote community, discourse, attention to family engagement, and build home-school connections (Borup, Jensen, et al., 2020), teachers need additional support in the area of trauma-informed teaching practices, given the traumatic nature of the COVID-19 pandemic (Horesh \& Brown, 2020) and the political and social climate. One free comprehensive resource that provides foundational training for educators in this area is called A Trusted Space (All It Takes, 2020). The resource, developed with the Learning Policy Institute and USC's Rossier School of Education, guides educators in redirecting grief into growth for the students that they serve. Another valuable resource that scholars and educators can reference a comprehensive interdisciplinary review of trauma-informed practices in schools carried out by Thomas et al. (2019). The paper includes a table of trauma-related resources for educators focused on understanding the nature and impact of trauma, creating healthy school cultures, and self-care strategies for educators. 
The PD program described in this study can be replicated in other in-service teacher contexts. Like Trust and Horrocks (2017), we recommend that teachers within a community of practice are provided with opportunities to engage in ongoing learning and professional growth tailored to their individual needs. Additionally, the potential for the diffusion of innovation (Rogers, 2003) exists, as at least half of the teachers in this study shared what they developed during the summer with their grade level teams during school pre-planning sessions. As an example, one teacher participant organized weekly Zoom meetings for all engineering teachers in their district and they led a PD session focused on trauma-informed teaching practices at their school. Another participant, new to their school and district, provided leadership by assisting other science teachers in setting up courses in Microsoft Teams. A third participant positively described presenting their summer PD project to their colleagues during a pre-planning department meeting. These types of leadership outreach were not anticipated, given the induction status of the teachers. The outreach highlights the potential ripple-effect of personalized, just-in-time teacher PD (Polly et al., 2020).

\section{Implications for theory}

This study has theoretical implications that offer potential avenues for future research. In this study, we put forth indicators of social engagement based on the work of Bond et al. (2020) and informed by Fredricks, Wang, et al. (2016). These social indicators are a first iteration that can be refined by other scholars interested in using student engagement indicators for coding purposes. Additionally, our analysis of the data using student engagement indicators (Bond et al., 2020) and trauma-informed teaching practices (Carello, 2020) indicated an overlap between these two constructs. Assuming some consensus in the professional education community regarding the value of all four engagement domains for supporting student learning, we are encouraged that these data potentially support the claim that trauma-informed teaching can strengthen student engagement (Rumsey \& Milsom, 2018), particularly in the affective and social dimensions of engagement during times of trauma and rapid online learning.

\section{Conflict of interest}

We have no known conflict of interest to disclose.

\section{Notes on contributors}

T. A. Roman, $\mathrm{PhD}$, is an Assistant Professor of Instructional Technology at Kennesaw State University in the School of Instructional Technology and Innovation. Her recent scholarship includes a focus on trauma-informed teaching practices, student engagement, and K-12 STEM education. Additionally, her research interests encompass the design and development of learning technologies, active learning classrooms, and design education, broadly conceived.

L. Brantley-Dias, PhD, is a Professor of Instructional Technology in the Department of Instructional Technology at Kennesaw State University. Her current scholarship and teaching focuses on helping teachers integrate technology, design instruction for meaningful learning, and use technology to facilitate teachers' reflection, professional growth, and development. Outside of the classroom, she enjoys facilitating professional learning opportunities for in-service teachers with a focus on STEM education.

M. Dias, PhD, is a Professor of Biology Education at Kennesaw State University, where he conducts science teacher education in coteaching roles with secondary science teachers. Michael's research on science teacher mentoring and inquiry learning inform his efforts to facilitate experiential science teacher education that narrows the practice-theory gap. Current scholarship deals with science teacher reflection and literacy support for discourse in biology education.

B. P. Edwards, $\mathrm{PhD}$, is a Professor of Mathematics Education at Kennesaw State University, where she conducts mathematics teacher education research in equitable methods of teaching mathematics in secondary classrooms. Related research includes developing bi-directional university-school partnerships that enable Preservice Mathematics Teachers to develop practice-based knowledge for teaching during early field experiences. 


\section{ORCID}

T. A. Roman (DD http://orcid.org/0000-0002-7172-8467

L. Brantley-Dias (D) http://orcid.org/0000-0002-0093-8272

M. Dias (ID http://orcid.org/0000-0001-5456-4918

B. P. Edwards (D) http://orcid.org/0000-0002-4367-1467

\section{References}

All It Takes. (2020). A trusted space: Redirecting grief to growth. Retrieved from https://allittakes.org/a-trusted-space/ Appleton, J. J., Christenson, S. L., \& Furlong, M. J. (2008). Student engagement with school: Critical conceptual and methodological issues of the construct. Psychology in the Schools, 45(5), 369-386. https://doi.org/10.1002/ pits. 20303

Boaler, J. (2016). Designing mathematics classes to promote equity and engagement. The Journal of Mathematical Behavior, 41, 172-178. https://doi.org/10.1016/j.jmathb.2015.01.002

Bond, M. (2020). Facilitating student engagement through the flipped learning approach in K-12: A systematic review. Computers \& Education, 151, 103819. https://doi.org/10.1016/j.compedu.2020.103819

Bond, M., \& Bedenlier, S. (2019). Facilitating student engagement through educational technology: Towards a conceptual framework. Journal of Interactive Media in Education, 2019(1), 1-14. https://doi.org/10.5334/jime.528

Bond, M., Buntins, K., Bedenlier, S., Zawacki-Richter, O., \& Kerres, M. (2020). Mapping research in student engagement and educational technology in higher education: A systematic evidence map. International Journal of Educational Technology in Higher Education, 17(1), 2. https://doi.org/10.1186/s41239-019-0176-8

Bonk, C. J., \& Khoo, E. (2014). Adding some TEC-VARIETY: 100+ activities for motivating and retaining learners online. OpenWorldBooks.com and Amazon CreateSpace.

Borup, J., Graham, C. R., West, R. E., Archambault, L., \& Spring, K. J. (2020). Academic communities of engagement: An expansive lens for examining support structures in blended and online learning. Educational Technology Research and Development, 68(2), 807-832. https://doi.org/10.1007/s11423-020-09744-x

Borup, J., Jensen, M., Archambault, L., \& Graham, C. R. (2020). Supporting students during COVID-19: Developing and leveraging academic communities of engagement in a time of crisis. Journal of Technology and Teacher Education, 28(2), 161-169. https://www.learntechlib.org/primary/p/216288/

Borup, J., West, R. E., Graham, C. R., \& Davies, R. S. (2014). The adolescent community of engagement framework: A lens for research on K-12 online learning. Journal of Technology and Teacher Education, 22(1), 107-129. https://www.learntechlib.org/primary/p/112371/

Bransford, J. D., Brown, A. L., \& Cocking, R. R. (2000). How people learn: Brain, mind, experience, and school: Expanded Edition. National Academy Press.

Bronfenbrenner, U., \& Ceci, S. J. (1994). Nature-nurture reconceptualized in developmental perspective: A bioecological model. Psychological Review, 101(4), 568-586. https://doi.org/10.1037/0033-295x.101.4.568

Brookfield, S. D. (2017). Becoming a critically reflective teacher (2nd ed.). Jossey-Bass.

Carello, J. (2020). Trauma-informed teaching and learning principles. Trauma-Informed Teaching \& Learning. https://traumainformedteachingblog.files.wordpress.com/2020/04/titl-general-principles-3.20.pdf

Carello, J., \& Butler, L. D. (2015). Practicing what we teach: Trauma-informed educational practice. Journal of Teaching in Social Work, 35(3), 262-278. https://doi.org/10.1080/08841233.2015.1030059

DeCuir-Gunby, J. T., Marshall, P. L., \& McCulloch, A. W. (2011). Developing and using a codebook for the analysis of interview data: An example from a professional development research project. Field Methods, 23(2), 136-155. https://doi.org/10.1177/1525822X10388468

Fallot, R., \& D., Harris, M. (2009). Creating Cultures of Trauma-Informed Care (CCTIC): A self-assessment and planning protocol. Community Connections. https://www.theannainstitute.org/CCTICSELFASSPP.pdf

Filsecker, M., \& Kerres, M. (2014). Engagement as a volitional construct: A framework for evidence-based research on educational games. Simulation \& Gaming, 45(4-5), 450-470. https://doi.org/10.1177/1046878114553569

Finn, J. D., \& Zimmer, K. (2012). Student engagement: What it is? Why does it matter? In S. L. Christenson, A. L. Reschly, \& C. Wylie (Eds.), Handbook of research on student engagement (pp. 97-131). Springer. https:// doi.org/10.1007/978-1-4614-2018-7_5

Fredricks, J. A., Blumenfeld, P. C., \& Paris, A. H. (2004). School engagement: Potential of the concept, state of the evidence. Review of Educational Research, 74(1), 59-109. https://doi.org/10.3102/00346543074001059

Fredricks, J. A., Filsecker, M., \& Lawson, M. A. (2016). Student engagement, context, and adjustment: Addressing definitional, measurement, and methodological issues. Learning and Instruction, 43, 1-4. https://doi.org/10.1016/j. learninstruc.2016.02.002

Fredricks, J. A., Wang, M.-T., Linn, J. S., Hofkens, T. L., Sung, H., Parr, A., \& Allerton, J. (2016). Using qualitative methods to develop a survey measure of math and science engagement. Learning and Instruction, 43, 5-15. https://doi.org/10.1016/j.learninstruc.2016.01.009

Frick, T. W. (2020). Education systems and technology in 1990, 2020, and beyond. TechTrends, 64(5), 693-703. https://doi.org/10.1007/s11528-020-00527-y 
Halverson, L. R., \& Graham, C. R. (2019). Learner engagement in blended learning environments: A conceptual framework. Online Learning, 23(2), 145-178. https://doi.org/10.24059/olj.v23i2.1481

Henrie, C. R., Halverson, L. R., \& Graham, C. R. (2015). Measuring student engagement in technology-mediated learning: A review. Computers \& Education, 90, 36-53. https://doi.org/10.1016/j.compedu.2015.09.005

Hodges, C. B., Moore, S., Lockee, B. B., Trust, T., \& Bond, M. A. (2020). The difference between emergency remote teaching and online learning. EDUCAUSE Review. https://er.educause.edu/articles/2020/3/the-differenc e-be-tween-emergency-remote-teaching-and-online-learning

Horesh, D., \& Brown, A. D. (2020). Traumatic stress in the age of COVID-19: A call to close critical gaps and adapt to new realities. Psychological Trauma, 12(4), 331-335. https://doi.org/10.1037/tra0000592

Horn, I. (2012). Strength in numbers: Collaborative learning in secondary mathematics. National Council of Teachers of Mathematics.

Jay, T., Rose, J., \& Simmons, B. (2018). Why is parental involvement in children's mathematics learning hard? Parental perspectives on their role supporting children's learning. SAGE Open, 8(2), 215824401877546. https:// doi.org/10.1177/2158244018775466

Johnson, N., Veletsianos, G., \& Seaman, J. (2020). US faculty and administrators' experiences and approaches in the early weeks of the COVID-19 pandemic. Online Learning, 24(2), 6-21. https://doi.org/10.24059/olj.v24i2.2285

Kahu, E. R. (2013). Framing student engagement in higher education. Studies in Higher Education, 38(5), 758-773. https://doi.org/10.1080/03075079.2011.598505

Kantamneni, N. (2020). The impact of the COVID-19 pandemic on marginalized populations in the United States: A research agenda. Journal of Vocational Behavior, 119, 103439. https://doi.org/10.1016/j.jvb.2020.103439

Krajcik, J. (2015). Three-dimensional instruction. The Science Teacher, 82(8), 50-52. https://doi.org/10.2505/4/ tst15_082_08_50

Krapp, A. (1999). Interest, motivation and learning: An educational-psychological perspective. European Journal of Psychology of Education, 14(1), 23-40. https://doi.org/10.1007/BF03173109

Liang, L., Ren, H., Cao, R., Hu, Y., Qin, Z., Li, C., \& Mei, S. (2020). The effect of COVID-19 on youth mental health. Psychiatric Quarterly, 91(3), 841-852. https://doi.org/10.1007/s11126-020-09744-3

Linnenbrink-Garcia, L., Rogat, T. K., \& Koskey, K. L. (2011). Affect and engagement during small group instruction. Contemporary Educational Psychology, 36(1), 13-24. https://doi.org/10.1016/j.cedpsych.2010.09.001

Lokey-Vega, A., \& Stephens, S. (2019). A batch of one: A theoretical framework for the personalized learning movement. Journal of Online Learning Research, 5(3), 311-330. https://www.learntechlib.org/primary/p/210639/

Lurie, N., Saville, M., Hatchett, R., \& Halton, J. (2020). Developing Covid-19 vaccines at pandemic speed. The New England Journal of Medicine, 382(21), 1969-1973. https://doi.org/10.1056/NEJMp2005630

Mahatmya, D., Lohman, B. J., Matjasko, J. L., \& Farb, A. F. (2012). Engagement across developmental periods. In S. L. Christenson, A. L. Reschly, \& C. Wylie (Eds.), Handbook of research on student engagement (pp. 45-63). Springer. https://doi.org/10.1007/978-1-4614-2018-7_3

Maltese, A. V., \& Tai, R. H. (2010). Eyeballs in the fridge: Sources of early interest in science. International Journal of Science Education, 32(5), 669-685. https://doi.org/10.1080/09500690902792385

Mayes, R., \& Koballa, T. R., Jr. (2012). Exploring the science framework: Making connection in math with Common Core State Standards. The Science Teacher, 79(9), 27-35. http://www.jstor.org/stable/43557604

Melnick, H., Darling-Hammond, L., Leung, M., Yun, C., Schachner, A., Plasencia, S., \& Ondrasek, N. (2020). Reopening schools in the context of COVID-19: Health and safety guidelines from other countries (policy brief). Learning Policy Institute. https://learningpolicyinstitute.org/product/reopening-schools-covid-19-brief

Mullis, I. V., Martin, M. O., Foy, P., \& Arora, A. (2012). TIMSS 2011 international results in mathematics. TIMSS \& PIRLS International Study Center.

Mullis, I. V., Martin, M. O., Gonzalez, E. J., \& Chrostowski, S. J. (2004). TIMSS 2003 international mathematics report: Findings from IEA's trends in international mathematics and science study at the fourth and eighth grades. International Association for the Evaluation of Educational Achievement.

Music, G. (2020). Covid, racism and Black Lives Matter: A deadly constellation. Developmental Child Welfare, 2(3), 197-207. https://doi.org/10.1177/2516103220959814

National Council of Teachers of Mathematics. (2014). Principles to actions: Ensuring mathematical success for all. National Council of Teachers of Mathematics.

NGSS Lead States. (2013). Next Generation Science Standards: For states, by states. The National Academies Press.

Patall, E. A., Cooper, H., \& Robinson, J. C. (2008). Parent involvement in homework: A research synthesis. Review of Educational Research, 78(4), 1039-1101. https://doi.org/10.3102/0034654308325185

Phelps, C., \& Sperry, L. L. (2020). Children and the COVID-19 pandemic. Psychological Trauma, 12(S1), S73-S75. https://doi.org/10.1037/tra0000861

Polly, D., Martin, F., \& Guilbaud, T. C. (2021). Examining barriers and desired supports to increase faculty members' use of digital technologies: perspectives of faculty, staff and administrators. Journal of Computing in Higher Education, 33(1), 135-156. https://doi.org/10.1007/s12528-020-09259-7

Redmond, P., Abawi, L. A., Brown, A., Henderson, R., \& Heffernan, A. (2018). An online engagement framework for higher education. Online Learning, 22(1), 183-204. https://doi.org/10.24059/olj.v22i1.1175 
Reeve, J. (2012). A self-determination theory perspective on student engagement. In S. L. Christenson, A. L. Reschly, \& C. Wylie (Eds.), Handbook of research on student engagement (pp. 149-172). Springer. https://doi. org/10.1007/978-1-4614-2018-7_7

Rogers, E. M. (2003). Diffusion of innovations (5th ed.). Free Press.

Roman, T. A. (2020). Supporting the mental health of preservice teachers in COVID-19 through trauma-informed educational practices and adaptive formative assessment tools. Journal of Technology and Teacher Education, 28(2), 473-481. https://www.learntechlib.org/primary/p/216363/

Rumsey, A. D., \& Milsom, A. (2019). Supporting school engagement and high school completion through trauma-informed school counseling. Professional School Counseling, 22(1), 1-10. https://doi. org/10.1177/2156759X19867254

Schön, D. A. (1987). Educating the reflective practitioner. Josey Bass.

Skinner, E., \& Pitzer, J. R. (2012). Developmental dynamics of student engagement, coping, and everyday resilience. In S. L. Christenson, A. L. Reschly, \& C. Wylie (Eds.), Handbook of research on student engagement (pp. 21-44). Springer. https://doi.org/10.1007/978-1-4614-2018-7_2

Smith, W. A., Allen, W. R., \& Danley, L. L. (2007). “Assume the position... you fit the description": Psychosocial experiences and racial battle fatigue among African American male college students. American Behavioral Scientist, 51(4), 551-578. https://doi.org/10.1177/0002764207307742

Substance Abuse and Mental Health Services Administration. (2014). Trauma-informed care in behavioral health services. Substance Abuse and Mental Health Services Administration. https://www.ncbi.nlm.nih.gov/books/ NBK207201/

Thomas, M. S., Crosby, S., \& Vanderhaar, J. (2019). Trauma-informed practices in schools across two decades: An interdisciplinary review of research. Review of Research in Education, 43(1), 422-452. https://doi. org/10.3102/0091732X18821123

Trust, T., Carpenter, J. P., Krutka, D. G., \& Kimmons, R. (2020). \#RemoteTeaching \& \#RemoteLearning: Educator tweeting during the COVID-19 pandemic. Journal of Technology and Teacher Education, 28(2), 151-159. https:// www.learntechlib.org/primary/p/216094/

Trust, T., \& Horrocks, B. (2017). 'I never feel alone in my classroom': Teacher professional growth within a blended community of practice. Professional Development in Education, 43(4), 645-665. https://doi.org/10.108 $0 / 19415257.2016 .1233507$

Veletsianos, G. (2020). The 7 elements of a good online course. https://theconversation.com/the-7-elements-of-a-goo d-online-course-139736

Xie, K. (2021). Projecting learner engagement in remote contexts using empathic design. Educational Technology Research and Development, 69(1), 81-85. https://doi.org/10.1007/s11423-020-09898-8

Yin, R. K. (2018). Case study research and applications: Design and methods (6th ed.). Sage.

Zepke, N., \& Leach, L. (2010). Improving student engagement: Ten proposals for action. Active Learning in Higher Education, 11(3), 167-177. https://doi.org/10.1177/1469787410379680 


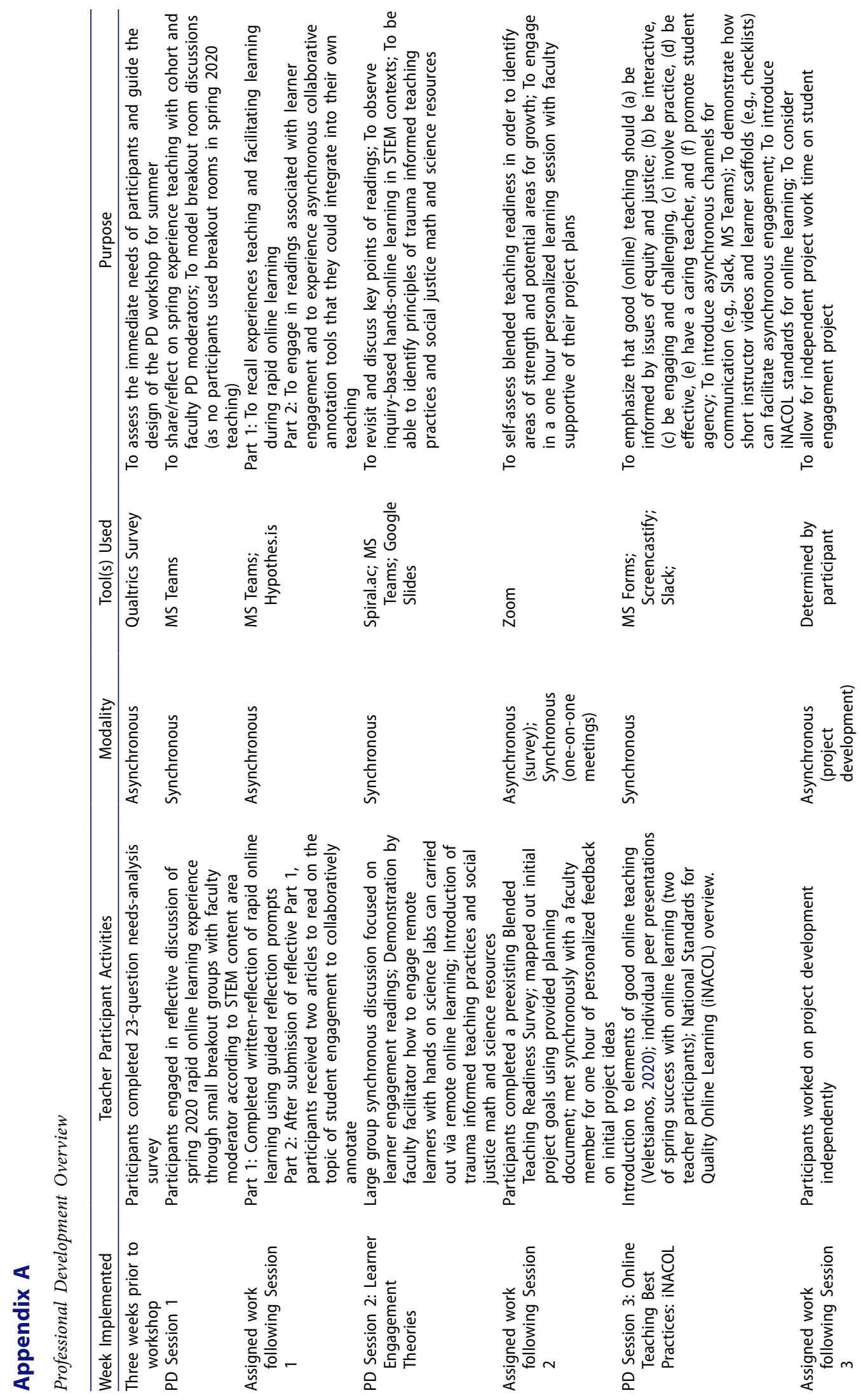



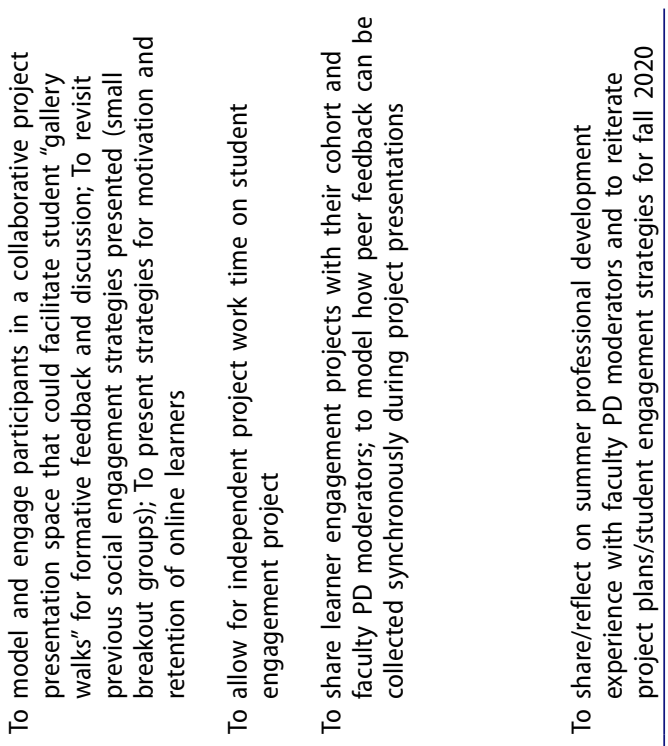

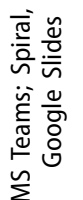

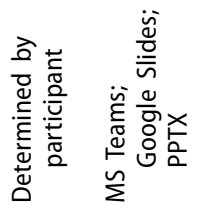

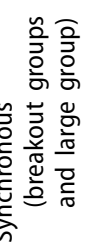

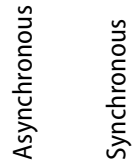

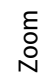

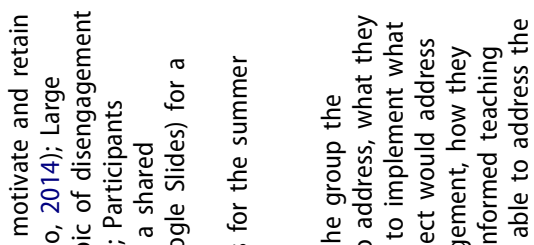

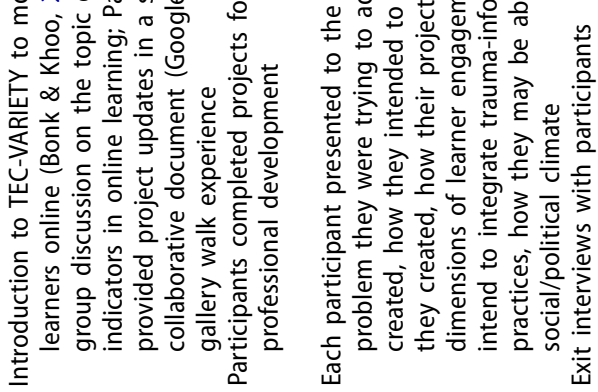

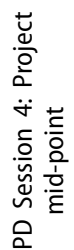

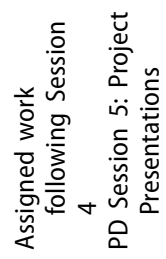




\section{Appendix B}

\section{Initial Reflection Prompts on Student Engagement}

\section{Rationale for Activity:}

During the past several months, you have experienced an unusual experience of remote emergency teaching (Hodges et al., 2020) and learning during the COVID-19 pandemic. As you prepare to learn some new techniques to promote student engagement for an online/blended learning environment, it is important for you to reflection on your experiences in order to make meaning and grow professionally. This is a form of reflection-on-action (Schön, 1987).

\section{Directions:}

To this end, we would like for you to reflect on the following questions and create thoughtful, rich responses to each one.

1. Define learner engagement as it relates to your discipline. Note: this is what you think it should be.

2. What did learner engagement look like in your face-to-face classroom before the pandemic?

3. Discuss any strategies that you employed or tried to employ in your face-to-face classroom to promote engagement. Did these work to your satisfaction? Why or why not?

4. What did student engagement look like in your online emergency remote-learning classroom?

5. Discuss any strategies that you employed or tried to employ. Did these work to your satisfaction? Why or why not?

6. What do you want student engagement to look like in your online/blended classroom should you work remotely in the upcoming academic year?

7. Think about this summer and what you might want to do or create in order to increase learner engagement in the fall if you need to teach online. What are some critical things you think would be helpful to do as a teacher to make sure that online learning is successful for your students?

\section{Appendix C}

\section{Exit Interview Questions}

1. Previously you defined learner engagement as [insert definition that the individual wrote prior to the summer PD]. Knowing what you know now, would you change or expand your previous definition of "learner engagement"?

a. What edits to that definition might you make?

2. How do you intend to approach learner engagement during online days this fall?

a. What factors will you look for this fall to see if your students are engaged online?

b. What teaching strategies do you plan to use to create a highly engaged classroom online?

3. As part of your Professional Development this summer, you created a project that you shared out to the group during the last synchronous session. Can you describe what you created?

a. What problem were you trying to address through the creation of this project?

b. What new skills or knowledge did you gain this summer that are reflected in the project (e.g., making an instructor screencast video for the first time in order to flip instructional time during sync sessions, creating a collaborative notebook space for your students

c. Within the project you created, what learner engagement strategies did you include and why?

d. Think on the dimensions of learner engagement. [Share Bond and Bedenlier's 2020 chart of learner engagement on screen to aid in recall-See Table 1]. What aspects of your project touch on those three dimensions of learner engagement?

e. Do you think you'll share your project with your colleagues at your school? Who might you share it with? How do you hope that they'll use it?

4. Before this PD workshop, on a scale of 1 to 10 , with 1 being not at all prepared and 10 being incredibly prepared, how prepared did you feel to design and implement instruction for rapid online learning/emergency remote teaching in spring 2020?

a. AFTER this PD workshop, on a similar scale of 1 to 10, how prepared do you feel currently to design and implement instruction for online/hybrid learning in fall 2020 ?

b. What did you learn this summer that impacts your perceptions of your ability to teach in an online/ hybrid manner? 
5. Has your school shared what the return to school will entail? What are the plans?

a. How will you tackle that approach this fall in your own classroom?

b. What factors, experiences, etc. inform these plans?

6. Face to face teaching this fall may involve socially distancing within classroom (if/when meeting face to face). If students must remain six feet apart, what types of instructional strategies would you like to employ to foster learner engagement in the classroom?

a. How might you enable collaboration in a physical classroom setting even if students are spaced at a distance?

b. What factors, experiences, etc. inform these plans?

7. During the summer PD, trauma-informed teaching practices and social justice resources were shared and discussed. What role do students' experiences during these challenging times play in your instructional decisions?

a. Share on screen the principles of trauma-informed teaching practices to help jog the memory of the Fellows)

i. Did you intuitively integrate any trauma-informed teaching practices listed here during the spring?

ii. Have you intentionally made any plans to address any of these this fall?

iii. If so, what do you plan to do? If not, can you explain why you might not explicitly address it?

b. Since emergency remote teaching ended in the spring, there has been social and political unrest.

i. Do you intend to address these issues this fall?

ii. If so, what do you plan to do/resources you plan to use? If not, can you explain why you might not explicitly address it?

8. Thinking to the fall and potentially the spring 2021 semester, what ongoing supports do you need to feel supported in blended/online teaching? 